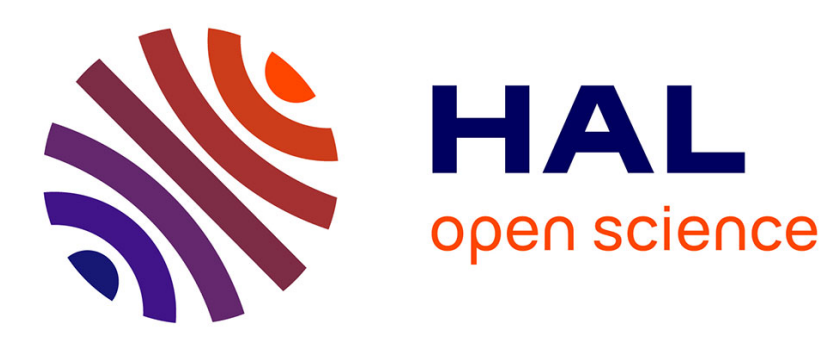

\title{
Inside the hybrid organization: An organizational level view of responses to conflicting institutional demands
} Anne-Claire Pache, Filipe Santos

\section{To cite this version:}

Anne-Claire Pache, Filipe Santos. Inside the hybrid organization: An organizational level view of responses to conflicting institutional demands. 2010, pp.64. hal-00580128v3

\section{HAL Id: hal-00580128 \\ https://essec.hal.science/hal-00580128v3}

Submitted on 17 May 2011

HAL is a multi-disciplinary open access archive for the deposit and dissemination of scientific research documents, whether they are published or not. The documents may come from teaching and research institutions in France or abroad, or from public or private research centers.
L'archive ouverte pluridisciplinaire HAL, est destinée au dépôt et à la diffusion de documents scientifiques de niveau recherche, publiés ou non, émanant des établissements d'enseignement et de recherche français ou étrangers, des laboratoires publics ou privés. 


\section{Inside the hybrid organization An organizational level view of responses to conflicting institutional demands}

\section{Research Center ESSEC Working Paper 1101 \\ February 2011}

Anne-Claire Pache

Filipe Santos 
Inside the hybrid organization:

An organizational level view of responses to conflicting institutional demands

Anne-Claire PACHE

ESSEC Business School

Avenue Bernard Hirsch

95021 Cergy Pontoise Cx - France

Email : pache@essec.fr

Filipe SANTOS

INSEAD

Boulevard de Constance

77305 Fontainebleau Cx

Email: filipe.santos@insead.edu

August 2010 


\title{
Inside the hybrid organization:
}

\section{An organizational level view of responses to conflicting institutional demands}

\begin{abstract}
This paper explores organizational responses to conflicting institutional demands. An inductive comparative case study of four social enterprises that scaled their organization while embedded in competing social welfare and commercial logics suggests that, when facing competing organizational templates imposed by their institutional environment, organizations attempt to strike a balance at the organizational level by adopting a combination of intact practices from both logics instead of balancing at the practice level by resorting to strategies such as decoupling. In addition, we find an important legitimating effect of founding origins: in a sector where the social welfare logic is ultimately predominant, organizations originating from the social sector benefited from an a priori legitimacy capital, which allowed them to borrow freely from both social and commercial practices. In contrast, organizations emanating from the commercial sector, suffering from an a priori legitimacy deficit, had to display their conformity with social templates in order to secure their acceptance in the field and therefore adopted predominantly social practices. Our findings contribute to a better understanding of hybrid organizations and point to the founding origins of organizations as an important determinant of the pattern of hybridization strategies.
\end{abstract}


There is a growing recognition that organizations are often exposed to conflicting demands from their institutional environment (Djelic \& Quack, 2004; Friedland \& Alford, 1991; Heimer, 1999; Kraatz \& Block, 2008; Ring, Bigley, D'Aunno \& Khanna, 2005; Scott, 1994). Organizations are indeed subject to a large number of uncoordinated regulatory, normative and cognitive pressures which require of them the adoption of goals or practices that may be at odds (Meyer \& Rowan, 1977). At the organizational field level, competing institutional demands originate from competing logics (Scott, 2001; Thornton \& Ocasio, 2008), i.e. conflicting conceptions about the appropriate goals to pursue as well as the appropriate means to achieve them (Scott, 1987). Earlier empirical explorations of the phenomenon of competing logics focused on the transitory phenomenon of the replacement of a dominant logic by an alternative one (Hoffman, 1999; Lounsbury, 2005; Nigam \& Ocasio, 2009; Rao, Monin \& Durand, 2003; Thornton, Jones \& Kury, 2005). This stream of research suggested that conflict in institutional demands is resolved at the field level by the progressive assimilation by the incumbent logic of features of challenging logics (Hoffman, 1999). However, organization scholars have started to recognize that when fields are fragmented and moderately centralized - i.e. when no institutional constituent clearly dominates the field yet several of them have enough power to constrain organizational actions - conflicting demands are not likely to be resolved at the field level and will be imposed on organizations (Pache \& Santos, 2010). Under such field configurations, organizations find themselves permanently embedded in competing logics (Dunn \& Jones, 2010; Purdy \& Gray, 2009; Reay \& Hinings, 2009) and need to resolve the resulting conflict. This places them in a challenging situation because satisfying one set of demands requires defying or ignoring the others (Pfeffer \& Salancik, 1978). The purpose of this paper is to investigate how organizations respond to these permanently competing institutional demands.

Two independent streams of research have explored the issue of organizational responses to competing institutional demands. The first stream focuses on decoupling as a 
response strategy to institutional pluralism (Boxenbaum \& Jonsson, 2008; Fiss \& Zajac, 2006; Meyer et al., 1977; Westphal \& Zajac, 1994; , 1998; , 2001). A more recent stream explores more broadly the impact of competing institutional logics on organizations (Battilana \& Dorado, 2010; Binder, 2007; Greenwood, Diaz, Li \& Lorente, 2010; Kraatz et al., 2008; Lounsbury, 2007; Pache et al., 2010; Reay et al., 2009; Tracey, Phillips \& Jarvis, 2010).

In the first stream, decoupling studies, which have a long tradition in institutional theory, predict that under conditions of competing institutional demands, organizations decouple their formal structure from their operational structure (Boxenbaum et al., 2008; George, Chattopadhyay, Sitkin \& Barden, 2006; Meyer et al., 1977; Scott, 2003). Organizational leaders symbolically adopt the structures or practices demanded by institutional referents to project a legitimate image, yet they do not actually implement these elements internally. Instead, they try to avoid the scrutiny of institutional referents (which should not discover the deceit) while adopting the practices that are aligned with their own institutional affinities. Both quantitative (Edelman, 1992; Kostova \& Roth, 2002; Westphal et al., 1994; , 2001) and qualitative (Aurini, 2006; Elsbach \& Sutton, 1992) empirical studies provide support for the prediction that decoupling is a viable response to competing institutional demands (Boxenbaum et al., 2008). Organizations have been shown to decouple when facing competing demands regarding quality management practices (Kostova et al., 2002; Westphal, Gulati \& Shortell, 1997), equal opportunity employment practices (Edelman, 1992), audit reporting processes (Basu, Dirsmith \& Gupta, 1999), the use of ethic codes (Stevens, Steensma, Harrison \& Cochran, 2005), the adoption of long term incentive plans for CEO compensation (Westphal et al., 1994; , 1998; Zajac \& Westphal, 1995), the adoption of stock repurchase programs (Westphal et al., 2001) and the adoption of a shareholder value orientation (Fiss \& Zajac, 2004; Fiss et al., 2006). Overall this stream of research suggests that when facing competing demands related to a given practice, organizations find ways to alter that practice in a way that makes it acceptable to all institutional referents. A limitation 
of this stream of research is that the focus on the practice level has hampered its ability to provide a comprehensive organizational level view of organizational responses to competing institutional demands. Another limitation of these predictions is that organizations permanently embedded in competing demands may find it difficult to avoid the scrutiny of institutional referents over the long term, which suggests that decoupling is a response strategy that is hard to sustain in such contexts.

In the second stream, recent studies attempt to predict how organizations respond to permanently competing logics (Battilana et al., 2010; Binder, 2007; Greenwood et al., 2010; Lounsbury, 2007; Reay et al., 2009). Empirical work in this stream provides support for the prediction that the availability of competing institutional models of action creates latitude for organizational members to exercise some level of strategic choice (Clemens \& Cook, 1999; Dorado, 2005; Seo \& Creed, 2002; Tracey et al., 2010), because it allows them to avoid the taken-for-grantedness of institutional prescriptions. When embedded amidst competing logics, organizational members become aware of alternative courses of action. They no longer blindly comply with institutional pressures and may enact, as a result, different types of responses. Battilana and Dorado (2010), for instance, show that two micro finance institutions embedded in competing banking and development logics mobilized alternative socialization and hiring strategies to balance the competing expectations of their institutional environments. In a similar vein, Greenwood et al. (2010) show that the competing influence of market, state and family logics led to variation in the willingness of manufacturing firms to downsize their workforce. This line of work has again focused on specific organizational practices such as hiring strategies (Battilana et al., 2010), workforce downsizing (Greenwood et al., 2010) or contracting strategies (Lounsbury, 2007). Therefore, it offers only a partial view of how competing institutional logics are dealt with at the organizational level.

In summary, whereas both decoupling studies and studies on competing logics offer useful insights into our phenomenon of interest, they assume that organizations manage the 
tensions of competing demands through independent practice-level decisions. This assumption, however, does not take into account the fact that organizations are actually systems of interrelated practices (Nelson \& Winter, 1982; Powell \& Colyvas, 2008). Organizational members may in fact choose to adopt certain configurations of practices or engage in balancing across practices (Oliver, 1991). For example, organizations may decouple a particular practice because they adhered to the stronger institutional prescriptions in other practices and have thus accumulated legitimacy capital. Or they may have been able to defy an institutional demand in one practice because of their efforts of appeasement through other practices. In the context of permanently competing institutional logics, where competing templates provide conflicting choices across many practices, organizational decision-makers are unlikely to make practice-level decisions in piece-meal fashion. By looking at isolated practices, without taking into account organizational level dynamics, researchers may have been "missing the forest for the trees".

This research project aims to address this gap. Our purpose is to develop an organizational level exploration of organizational responses to permanently competing institutional logics. How do organizational leaders configure their response strategies and why? What determines these configurations? Do organizations still resort to decoupling strategies in situations of permanent conflict or do they mobilize alternative strategies? So far these questions have been left largely unanswered. To shed light on this phenomenon, we conducted an inductive comparative case study in the field of "social integration enterprises" in France. Social integration enterprises aim at reintegrating long term unemployed people on the job market by hiring them to produce goods and services that are sold on the commercial market. By virtue of their goal and their operating principles, these organizations are rooted in competing social welfare and commercial logics. In the context of this study, we decided to explore more specifically the way in which four social integration enterprises combined these two logics as they organized their operations to achieve a national scale. 
Our study deepens the understanding of the implications of institutional pluralism for organizations (Kraatz et al., 2008) and makes two important contributions. First, it highlights that organizations embedded in competing institutional logics balance conflicting demands at the organization level, rather than at the practice level, by strategically combining intact practices drawn from each logic. This strategy allows organizations to reduce the risks and costs of decoupling and hybridizing practices, which are particularly taxing in situations of permanently competing logics. Second, it identifies the organizations' initial legitimacy capital as an important determinant of the configuration strategy adopted. Organizations benefiting from a priori legitimacy seem able to borrow freely from both logics to develop a hybrid template. In contrast, organizations suffering from an a priori legitimacy deficit overcompensate for this vulnerability by displaying an almost full adhesion to the predominant logic in the field. We further show that the founding origins of organizations play an important role in determining this initial stock of organizational legitimacy.

Overall, our paper opens the black box of hybrid organizations, defined as organizations that are able to integrate competing logics in unprecedented ways (Scott, 2001). It identifies how hybrid organizations are formed and explains when and why hybrid organizations' leaders are capable of taking advantage of the wide repertoire of organizing templates available to them in the context of competitive institutional environments. As such, it sheds light on the phenomenon of hybrid organizations, which is increasingly common and yet poorly understood.

\section{METHODS}

The study used a comparative case study design (Eisenhardt, 1989) allowing for a replication logic (Yin, 2003) in which the cases are treated as a series of independent experiments that confirm emerging theoretical insights. The research setting is the field of "social integration enterprises" in France. Social integration enterprises are private 
commercial companies - operated as for profit or nonprofit entities - which aim at providing long term unemployed people with job opportunities in order to train or retrain them into the practices and behaviors of working as an employee.

Social integration organizations achieve their goal by hiring, for a limited period of two years, jobless people to produce products and services (construction, catering, gardening, recycling, temp work, etc.) that the organizations then sell on the market. With close mentoring, adapted training programs, as well as individual social counseling, these enterprises help long term unemployed people readapt to the world of work and regain individual pride and confidence. Organizations receive an accreditation from the State to operate as social integration enterprises, which entitles them to a public subsidy intended to offset the opportunity cost of employing less productive people who require extra supervision $^{1}$. About 1100 such organizations operate across France, employing 25000 former jobless persons and generating more than one billion Euros in revenues yearly (see Appendix 1 for more details about the field and its history).

By way of their mission and their web of public and social partners, social integration enterprises are embedded in a social welfare logic. By way of their commercial activity, from which they derive, on average, 80 percent of their revenues, they are also permanently rooted in a competing commercial logic, promoted by clients and industrial partners. Social integration enterprises' dependence on these two webs of support to survive makes their demands particularly salient, turning the field into a particularly rich setting to explore responses to enduringly competing demands.

In terms of sampling strategy, we decided to focus on four multi-site organizations that had attempted to reach a national scale. The scaling-up process requires from organizations to make strategic decisions about organizational structure and design at a time when social and

\footnotetext{
${ }^{1}$ They receive 9681 euros for each social employee hired, except temp work social integration enterprises which receive 51000 euros to hire a social and professional counselor to coach 12 FTE social employees.
} 
material support is particularly critical. This makes the conflict among institutional prescriptions particularly salient. By intensifying the experience of competing institutional demands, as well as the risks incurred when defying them, the scale up process provides a particularly rich setting for an exploration of organizational responses.

The organizations in our sample were selected from two separate industries in order to generate diversity in the observations and produce, as a result, a richer and more generalizable theory. Organizations were further selected on the basis of their founding origins (founded by a social organization vs. founded by a commercial organization) to explore the strength of founding imprint. The four cases thus constituted two matched pairs. One pair operated in the recycling industry (SOCYCLE and BUSITECH) while the other operated in the temp work industry (TEMPORG and WORK\&CO). In each pair, one organization was founded by a prominent social sector organization (SOCYCLE and TEMPORG) while the other emanated from a large multinational corporation (BUSITECH and WORK\&CO). The sampling strategy is thus one of 1 ) contrast within matched pairs that vary in a variable of theoretical interest (the founding origins of the organization) for explaining the phenomenon under study and 2) replication across pairs from different industries to improve the generalizability of the inducted theory. Table 1 describes the four cases analyzed in the paper.

Insert Table 1 about here

\section{Data collection}

Our study includes both archival and interview data, collected at both the organizational and field levels. We started the data collection process by gathering information about the field of social integration enterprises in France, its history as well as its legal environment through various sources (Ministry of Work, social integration enterprises federation, websites on social entrepreneurship, books and articles etc.). We also conducted interviews with 14 field experts to understand their views on the evolution of the field and the 
competing institutional logics that permeate it. These interviews were conducted both before and after the collection of case data.

We collected case data between 2007 and 2008 through interviews as well as secondary sources. For each enterprise, we gathered and read all available published material (annual reports, press articles, etc.). We conducted semi-structured interviews with a number of internal and external informants ranging from 7 to 17 , depending on the size of the organization. Internal informants systematically included board members, executive directors, technical supervisors and social workers. In some cases, we also interviewed external informants such as funders, partners and clients. We met with the informants in their organization, where we spent between 2 and 5 days. This physical presence allowed us to get a sense of the culture and norms within each organization. We conducted a total of 62 interviews which lasted between 30 minutes and 3 hours, amounting to a total of 91 hours of interviews. All interviews were taped and transcribed. We used an interview guide to conduct the interviews. The guide was organized around seven categories: founding and growth, organizational structure and governance, human resources, commercial strategy, financial strategy, performance, environment and stakeholders. Informants were asked to explain how their organizations were founded, how they grew, how they were organized in 2007 and why they had decided to organize in such a way. This wealth of data allowed us to gain an in-depth understanding of the cases as well as the field of social integration enterprises in France.

\section{Data Analysis}

In a first step, relying on both the cases and the field-level data, we developed an analysis of the competing social welfare and commercial logics guiding organizational behavior in the field. To develop this preliminary analysis, we relied on institutional logics as a method of analysis (Thornton et al., 2008). Institutional logics are "the socially constructed, historical patterns of material practices, assumptions, values, beliefs and rules by which individuals produce and reproduce their material subsistence, organize time and space, and 
provide meaning to their social reality” (Thornton \& Ocasio, 1999). More simply put, they are the taken for granted social prescriptions guiding behavior of actors in a given organizational field: they define what actors in a field understand to be the appropriate goals as well as the appropriate means to achieve these goals (Scott, 2001). The power and influence of institutional logics reside in their pervasiveness. Field level logics are influenced by broader societal logics such as the state, the market, the democracy, the family or the religion (Friedland et al., 1991) and influence individuals' behavior by providing templates for action. We started by identifying the prescribed goals and practices for the two competing logics in which social integration enterprises in France were embedded. We did so based on the data collected and the support of two expert informants in the field, who confirmed that our description of the logics competing at the field level was accurate.

We then analyzed the data by first building a case report for each of the cases, describing the profile of informants and of key organizational members (founders, board members, key executives), the organizational structure, the values and practices adopted by each organization, as well as the justification of these values and practices by organizational informants. We then conducted a cross case analysis (Eisenhardt, 1989) to identify differences and similarities as well as common patterns. We developed tables and graphs in order to facilitate comparisons, which were conducted iteratively with various permutations of pairs. In particular we found that industry differences (temp work versus recycling) were not of conceptual importance to understand our findings but that the founding origins did have meaningful implications for the process under study, which led to further analysis and theorizing. This process led to the insights presented below. First, we describe the two competing logics in which the field of social integration in France is embedded. We then present the two response patterns that we identified and discuss the theoretical implications of these findings for understanding how organizations that are permanently embedded in competing institutional logics manage these tensions at the organizational level. 


\section{COMPETING SOCIAL WELFARE AND COMMERCIAL LOGICS IN THE FIELD OF SOCIAL INTEGRATION ENTERPRISES}

As commercial organizations with a social mission, social integration enterprises are embedded in two distinct institutional spheres, in which the cultural beliefs and rules that structure cognitions and shape actions are not only different but potentially conflicting. On the one hand, to recruit and mentor social employees as well as to secure financial support for their social mission, they are in close interactions with national and local state agencies as well as local nonprofit social agencies, which are participants in a belief system which we qualify here as the social welfare logic. On the other hand, to secure their market sustainability, they rely on clients as well as industrial partners, which are embedded in a commercial logic These two logics promote, in the field of social integration enterprises, contradicting rules of action as well as organizing principles (Reay et al., 2009). The dependence of these organizations on the two spheres to accomplish their mission and, more critically, to survive, makes the demands of each sphere not only pressing but inescapable. These two belief systems and their associated practices surfaced readily in our interactions with our various informants. We describe below the key characteristics of these logics.

The social welfare logic refers to the way in which social welfare goals have shaped norms, values and practices in the field. It is structured around a clear desired goal: addressing local social needs and is infused, in France, with the broader societal State logic (Friedland et al., 1991). In the field of social integration enterprises, the desired goal is reintegrating longterm unemployed people on the job market and helping them regain confidence and self esteem. The focus on the fulfillment of social needs posits that reaching out to local constituencies, making the efforts to understand local needs and adapt to them are key demands that social organizations must satisfy (Di Maggio \& Anheier, 1990). Social needs related to work integration are, in nature, localized, since they concern people and depend 
upon a variety of local factors including, among others, the composition of the population, the state of the local economy and local job market, the state of the local housing market, as well as the nature of the local social net. Under the social welfare logic, responses to social needs are thus perceived to be best conceived at a local level, where they can take into account the strengths and weaknesses of the local context. The responsiveness to social needs is thought to be better achieved through a participative organizational structure, as well as a democratic governance model, where the communities served, the local organizations representing them, as well as social partners, have a say in the decisions taken by organizations (Frumkin, 2002).

The commercial logic refers to the way in which commercial goals have shaped norms, values and practices in the field of social integration. Embedded in a larger societal Market logic (Friedland et al., 1991), it is structured around a clear goal: selling products and services on the market to generate as much profit as possible that can ultimately be legitimately appropriated by shareholders. The commercial logic rewards efficiency and control (Alexandrer \& D’Aunno, 2003). Pressures for efficiency presuppose that there are optimal ways to get organized to rationalize costs and maximize profits. Control is recognized as an appropriate governance mechanism because of the legitimacy of the proprietary claims of stakeholders and as an efficient means to sustain consistency (Fligstein, 1996). Hierarchical control, rather than democratic control, is viewed as the efficient way to coordinate collective behavior. With competition a salient feature of the commercial logic (DiMaggio \& Anheier, 1990; Hansmann, 1980), the survival of players in the market depends on their ability to differentiate themselves from competitors and to sustain some sort of competitive advantage. Predictability in the quality of a service or product is a key determinant of purchase: consistency and uniformity in production are a source of sustainable revenues. As stated by the executive director of SOCYCLE: "If we want to work in the Waste Electrical and Electronic Equipments industry, there will be two, three contractors organizing a call for 
tender in one region, where 4 to 5 of our sites have to cooperate, to bid together with similar services, similar quality (...).”

The social integration field in France is thus embedded in these two competing logics. These logics and their associated demands permeate organizations through the pressures for compliance exerted by institutional referents, such as funders, professional organizations or regulators (Scott \& Meyer, 1991), as well as through organizational members who, by way of their training or their experience, have been socialized into specific logics (Greenwood \& Hinings, 1996). Table 2 summarizes the belief systems that characterize these two competing logics and how they play out in the field of social integration enterprises.

Insert Table 2 about here

It is important to note that, after 30 years of existence, the field of social integration in France is still a terrain of institutional conflict. These tensions are reflected in the struggle that took place during the 2008 board elections of the national federation of social integration enterprises: a group composed of the social workers who had led the national federation since its founding and a group composed of younger professionals, adhering more readily to the commercial logic, competed fiercely for the leadership of the professional organization. While the younger professionals eventually won the election, tensions in the field remained palpable, as suggested by this quote from one expert informant: "The new team will have to find a way out of the crisis. (...) There will be wounds, because harsh words have been told." On the basis of previous research, one would have expected that, over years, one of the two competing social and commercial logic might have gained dominance over the other and progressively replaced it (Rao et al., 2003; Thornton, 2002; Thornton et al., 2005) or that a new logic would have emerged as a synthesis of the two (Chen \& O'Mahony, 2006; Glynn \& Lounsbury, 2005; Thornton et al., 2005), ultimately providing field actors with undisputed organizing templates (Friedland \& Alford, 1991). However, by highlighting the persistence of 
competing organizing templates long after the field's creation, our field-level data confirms that some field configurations expose organizations to permanent competing logics. We now turn to the core of our findings, highlighting how competing logics are experienced by social integration enterprises and what strategies they mobilize to manage these tensions.

\section{FINDINGS}

Our data suggest that the competing logics at play at the field level are surprisingly reconciled at the goal level, yet translate into important tensions at the practice level, exposing social integration entrepreneurs to competing organizing templates. We also find that decoupling is only a marginal strategy for organizations embedded in such contexts. When facing competing organizing templates, organizations hybridize them at the organizational level by adopting a combination of intact practices from either logic rather than by hybridizing each practice. Finally, the data shows that the founding origin of the organization has an important influence on how this combination of pure practices is assembled. We develop these findings in the next sections.

\section{Convergent goals and competing practices}

Past research on conflicting logics has emphasized the tensions emerging from competing conceptions of what goals the organization should pursue (Pache et al., 2010; Powell \& Friedkin, 1986; Purdy et al., 2009) and their pervasive impact on intra organizational dynamics (D'Aunno, Sutton \& Price, 1991; Glynn, 2000; Zilber, 2006). In the context of social integration enterprises, the embeddedness in competing social welfare and commercial logics could have translated into two competing conceptions of the core purpose of these organizations: addressing social needs vs. generating and redistributing profits, with an attempt by organizations at balancing these goals by finding a suitable compromise.

Surprisingly, the data from this research suggest that there was a very strong fieldlevel consensus about the appropriate goal of social integration enterprises: all informants, 
enterprise members as well as experts in the field, without a single exception, stated that the goal of social integration enterprises was to reintegrate long term unemployed people on the job market. When asked about their knowledge of companies which might have adopted a profit generation and redistribution goal, informants cited rumors but could not cite any concrete case that they had encountered. A field expert commented: "In theory, an entrepreneur could use the social integration vehicle to mobilize public funds and make money. Yet I have never seen this happen. The role played by the accreditation commission is key and the regional social integration enterprises union, which is a member of that commission, has a lot of influence in the process: they know the applicants well because they have usually accompanied them through the application process. If they have a doubt, they voice it and are usually listened to by the commission."

The data thus suggest that conflict on goals is resolved at the field level by the State, which grants social integration enterprises with the right to operate. The accreditation process is managed at the local level by the local office of the Ministry of Work. This office, after consultation with a commission composed of local representatives of the state, local governments, local elected officials, the national agency for employment, the regional social integration enterprises union, professional organizations and workers' unions, allows the state to contractually define and closely monitor the purpose of the accredited organizations. Not only does the process allow the State to keep illegitimate organizations from joining the field, but it also allows it to expel accredited organizations out of the field if they fail to meet their social obligations. This control is reinforced by the filter operated by the National Agency for Employment on the recruitment of social employees: social integration enterprises are constrained to recruit social employees among the people identified as "in need for social integration” by this national agency. This process keeps organizations from requesting the accreditation without complying with its social integration objectives. When asked about a possible corruption of the social objective, a field expert explained: "Making money with a 
social integration enterprise is not really possible because of the costs related to the lower productivity of social employees as well as the cost of turnover. The main risk is for social integration enterprises to hire people who do not need social integration. Everyone has done that occasionally. The real problem starts when they do it systematically. But that is not possible because of the control operated by the National Agency for Employment.”

This finding echoes early conceptualizations of field structures that characterize fields on the basis of their degree of fragmentation as well as their degree of centralization (Meyer, Scott \& Strang, 1987). The field of social integration in France appears quite fragmented (Scott et al., 1991). Social integration enterprises depend upon a wide range of actors to operate and achieve their mission: the national state, local governments, the national agency for employment, clients, funders, social partners, each with a say on what social integration enterprises should do and how they should get organized. However, this fragmented field is quite centralized (Scott et al., 1991) since it is dominated by an undisputed central actor, the national state, which grants social integration enterprises with the right to operate, grants them with financial compensation for the social mission that they perform, as well as controls, through the state-run national agency for employment, the social employees that they hire. This central actor thus resolves potential conflict on goals at the field level (Pache et al., 2010): actors that promote and endorse alternative goals within the field lose their right to operate and are, as a result, expelled from the field (Scott et al., 1991). As a consequence, organizations within the field display a very high level of goal congruence.

Yet, although actors in the field have reached consensus about the goal of their organizations, they exhibit strong contradictory beliefs about what are the appropriate practices to implement when organizing operations at a national scale. The process of expanding operations in multiple geographic areas requires from organizations to make key strategic decisions regarding organizational design and governance. These decisions are made at a time when social and material support is particularly important for organizations, thus 
making institutional demands not only salient but also challenging to defy. The difficulty is that in the absence of centrally prescribed organizing templates, there is ample room for disagreement amongst institutional referents at the field level about the appropriate practices that organizations in the field should deploy.

A set of competing practices indeed emerged from our data. In congruence with research on organizational design (Chandler, 1977), we identified in our data two key organizational dimensions, structure and operations, in which practices competed. By structure, we mean the elements that define, in a constraining and enduring way, the architecture of the organization. By operations, we mean the elements mobilized on a day to day basis to achieve organizational objectives. In terms of structure, there was indeed evidence, at the field level, that the two competing social welfare and commercial logics promoted competing practices related to what organizational form to choose for sites, what legal status to adopt, and what ownership structure to set up. In terms of operations, there was evidence of competing conceptions related to what profit destination to favor, what degree of local embeddedness to nurture, what brand to develop, what procedures to localize or standardize, what monitoring to implement at central level, what professional affiliation to opt for and, finally, whether or not mobilization of volunteers is appropriate.

The social welfare logic, in accordance with its principles and values, promotes a structure founded upon the creation of sites as autonomous local entities, the use of the notfor-profit legal form, and ownership tied to an adhesion to the mission. At the operational dimension, it promotes the absence of profit redistribution, a governance model strongly embedded in a network of local actors, the adaptation of the brand and of procedures to local conditions, adhesion to the social integration professional organization, and the mobilization of volunteers for permanent operational positions.

These prescribed practices contrast with those promoted by the commercial logic, which promotes a structure based on the creation of sites as wholly owned subsidiaries of the 
mother organization, the use of the for-profit form, and ownership tied to capital. At the operational dimension, the commercial logic promotes the systematic redistribution of profit to shareholders, the absence of involvement of local actors in site governance, the development of an unified brand, the design and enforcement of standard operating procedures associated with close monitoring of local practices by the central organization, an adhesion to the industry professional organization, and the mobilization of paid staff only (not volunteers) for permanent operational positions.

Importantly, these competing demands are imposed on social integration enterprises by a combination of internal and external actors. Social welfare practices are internally endorsed and enacted by organizational members professionally socialized as social workers. These practices are also demanded by external social partners, who provide social integration enterprises with recruitment and training support for social employees, as well as public bodies that provide funding and accreditation, and charitable funders. Commercial practices are internally endorsed and enacted by managerial and technical staff recruited to manage commercial and production operations, as well as externally demanded by clients and industrial partners. Although none of the identified competing practices is imposed on organizations by regulatory or coercive mechanisms, data suggests that they are strongly institutionalized at the field level. The taken-for-grantedness of these practices is vividly illustrated by quotes from informants. A social partner of BUSITECH explains how they chose their legal status: "We thought about creating a nonprofit because as trade unionists, we were not going to create a for-profit company". WORK\&CO's national coordinator commented on how members of MULTIWORK, their multinational mother organization, reacted when WORK\&CO decided to develop new local sites as autonomous organizations: "Their problem was not to invest capital (in the new sites), because investing capital is business as usual for a company like MULTIWORK (...) but what was atypical was to create autonomous legal entities, because at MULTIWORK, they create clones or secondary 
establishments." Various informants mentioned, in addition, that deviating from some of these practices could cause them to lose important support. The executive director of a TEMPORG site reflects upon his affiliation to the temporary work professional organization: "It is as simple as that: if you don't have it, no one takes you seriously. No one wants to do business with you". Finally, some practices are reinforced by funding criteria chosen by funders. BUSITECH's founder explains: "Foundations and corporations are only going to give their charitable Euros to nonprofit organizations. So if you don't have one, you are in trouble." This normative pressure is confirmed by one of SOCYCLE's founders: "If the creation of a project relies a lot on public funds, then it is safer that control be exercised by people who are not involved either as owners or as managers of the organization". Overall, data suggests that these prescribed practices are not only conflicting but also constraining for organizations and not easy to ignore or defy.

We summarize in table 3 the ten practices we identified in the data, being specific about their content and how we measured them. We also provide a description of the respective prescriptions for each practice, together with supportive quotes.

Insert Table 3 about here

In summary, by operating in a field embedded in enduring competing logics in which a central actor had resolved the potential conflict regarding organizational goals, the main challenge for social integration enterprises is to figure out how to cope with the competing conceptions of what practices are required to achieve that goal. We describe next the response patterns that we identified in the data.

\section{Hybridizing practices at the organization level}

When faced with competing templates about how to get organized to scale up, social integration enterprises are faced with a dilemma since complying with one set of demands 
requires from them to defy competing others (Pfeffer et al., 1978). An important risk associated with the choice of a given response is to jeopardize the organization's legitimacy: promoters and enforcers of a given logic may decide to withdraw their support to organizations that depart from the prescribed template. For example, funders may refuse to give grants or subsidies to organizations that do not display the appropriate legal status and local actors may limit their collaboration with organizations that do not give them a say in their local governance structure.

Previous research suggests that, under such conditions, organizations are likely to resort to decoupling as a response strategy (Elsbach et al., 1992; Fiss et al., 2006; Meyer et al., 1977; Westphal et al., 2001). Decoupling is particularly adapted to situations where practices promoted by external institutional referents conflict with internal institutionalized practices promoted by professional actors (Boxenbaum et al., 2008; Greenwood et al., 1996). In that case, organizations symbolically adopt the externally promoted practice while actually not implementing it. What they actually implement is the practice that is coherent with their internal institutional influences. Such a strategy increases an organization's chance of survival as it prevents conflicts from escalating between internal and external institutional referents. It thus becomes a safeguarding mechanism to minimize the risk of legitimacy threats (Boxenbaum et al., 2008; Brunsson, 2002). Importantly, most current research on decoupling suggests that a balance between symbolism and substance is enacted for each competing practice. For example, although organizations formally adopted corporate governance policies (Westphal et al., 2001), affirmative action policies (Edelman, Abraham \& Erlanger, 1992) or quality management practices (Kostova et al., 2002), they actually implemented alternative policies and practices. Thus, research suggests that the balance between competing institutional demands is made at the practice level.

Yet, our data suggests that such strategies that involved trade-offs at the practice level were only marginal. In contrast we find evidence of an alternative strategy that involved the 
combination of intact practices promoted by either of the competing logics. The compromise was then made at the organization level, not the practice level. SOCYCLE provides a compelling illustration of this pattern. Only two out of ten practices were hybridized in such a way to at least partially satisfy both logics, including one that exhibited decoupling and one that exhibited a compromise. Specifically, in terms of legal status of sites, SOCYCLE adopted a combination of for profit and nonprofit forms, sending the signal of adhesion to both logics. In terms of standardization practices, SOCYCLE adopted a decoupling approach: it officially adopted rigorous standard operating procedures across sites, however, when looking more closely, it was clear that these procedures were not implemented at the site level, which exhibited local autonomy and variance in procedures. Yet, SOCYCLE's response strategy was different on the eight other scale-up practices. Five of the adopted practices were intact social welfare practices. SOCYCLE respected the substance of social prescriptions regarding how to structure the network of sites: it developed its sites as autonomous entities, all of which were "owned" by strong advocates of the mission of the organization. All for-profit sites, in particular, were owned by a local SOCYCLE nonprofit to "ensure that control be exercised by people who are not directly involved as shareholders or managers". This ownership structure implied, in addition, the profit destination model prescribed by the social welfare logic: profits generated in the for-profit sites were distributed to the non-profit owner, which, just as non-profit sites, used these resources to further the organization's mission. The governance model designed by SOCYCLE emphasized, as promoted by the social welfare logic, local embeddedness. Control over sites was exercised by local volunteer boards of directors, which mobilized key local actors (local public officials, social partners, business partners, experts). As explained by a SOCYCLE executive: "Local sites were built on strong local roots, with strong political support. SOCYCLE succeeded because the social project was strong and because the individuals promoting it were strong too.” Finally, SOCYCLE required, from all sites, to affiliate with the local social integration professional union, as a 
way to demonstrate their connection with the sector. In addition to these five intact social welfare practices, SOCYCLE also adopted four intact commercial practices. SOCYCLE invested in a strong national brand, a practice promoted by the commercial logic. Not only did all sites bear the same name (with the name of the city next to it), but they all shared a similar visual identity and developed, a joint website. Very early on, SOCYCLE developed a national organization, in charge of development, monitoring and control, in order to ensure standardization of operations at the national level. A co-founder explains: "SOCYCLE started out as a very tight and controlled group. This tight structure was very important early on, because it allowed us to develop the model and to make sure it would not be perverted." Important resources were mobilized and allocated to ensure this monitoring and control function at national level. Fourteen staff members were mobilized at the national level, financed for 60 percent by the local sites who contributed three percent of their turnover to the national organization. Finally, SOCYCLE required from all of its sites to affiliate with the waste management professional organization. Overall, SOCYCLE managed its embeddedness in competing logics not so much by decoupling its practices, but rather by designing a hybrid combination of intact practices borrowed from both logics. The overall pattern of responses is described in table 4 .

Insert Table 4 about here

We observed very similar patterns in the other three cases. TEMPORG, for instance, also adopted eight intact practices out of ten. Complying with the commercial logic, it chose a for profit legal status, developed its sites as branches of a national organization, developed a common brand identity, mobilized a lot of resources to monitor and control operations at the national level, required from all sites to affiliate with the temp work professional organization, and ignored volunteers as a potential resource. In compliance with the social welfare logic, it chose not to redistribute any dividends to shareholders, developed local 
ownership by mobilizing local advisory boards composed of local stakeholders, and required from all its sites to affiliate with the social integration professional organization. TEMPORG did not decouple any practice but hybridized two of them. It developed a hybrid ownership structure, combining mission holders (not-for-profit shareholders, for 59 percent) and capital holders (private for profit investors, for 41 percent). In terms of procedures, TEMPORG standardized a wide range of procedures (HR, accounting, IT, training), yet gave its sites full autonomy over pricing and sales. TEMPORG's full response strategy is presented in table 5.

Insert Table 5 about here

Similar patterns applied to BUSITECH and WORK\&CO: both organizations adopted seven intact practices drawn from either logic. Each organization decoupled only one practice and hybridized two. Tables 6 and 7 detail their response configurations.

Insert Table 6 about here

Insert Table 7 about here

Table 8 summarizes the adoption profiles of all four organizations. It is clear that, in contrast to what is suggested in the literature, only one in four practices (10 out of 40) exhibited an attempt to balance competing demands at the practice level, through decoupling or hybridizing strategies. Most of the practices adopted by organizations were intact practices from either logic.

Insert Table 8 about here

Interestingly, these configurations appear to be very stable over time: across all organizations, 80 percent of the practices enacted in 2007 were similar to those put in place in the early scale up phase. This suggests that the pattern identified is neither temporary nor 
unstable. Rather, the configurations of practices mobilized appear as lasting commitments to a "way of doing things”. Data even suggest that such configurations are hard to change: in 2007, the leaders of two organizations expressed their desire to change some of the practices. SOCYCLE's leader for instance noted that when the opportunity to invite private investors as shareholders of the for-profit sites was discussed, "it was a revolution that was not easy to deal with. There was real resistance to change. The old timers, the early activists in the network, thought that we were deviating from our social mission, from our social integration mission, that we embraced a business goal, whereas for us, it was just a means (...)." Similarly, the national coordinator of WORK\&CO explained its difficulties to convince the managers of the local sites to adopt a unified brand, reflecting their affiliation with their multinational parent: "the social integration company is their toy, they don't want their mother organization to appropriate it."

Overall, this analysis indicates that organizations do, on a lasting basis, attempt to balance the competing expectations of institutional referents, yet they do so predominantly at the organization level rather than at the practice level. And while we found instances of decoupling at the practice level, as suggested by the wealth of decoupling studies in institutional theory, these remained atypical, rather than predominant. Various factors might explain this pattern. First, in the case of a lasting embeddedeness in competing institutional logics, organizations may find it difficult to avoid the scrutiny of institutional referents, as required by decoupling strategies (Boxenbaum et al., 2008; Meyer et al., 1977). Over the long run, the repeated interactions and social connections inherent to any lasting field's social system are likely to expose organizations to the inspection of other actors, thus making it hard to fake institutional compliance without running the risk of losing face. In contrast, the pattern that we uncovered, which entails the actual adoption of pure practices, allows organizational leaders to strategically adopt the practices that they believe best fits with their institutional 
attachments, thus enabling them to build confidence with their institutional referents (Haveman, 2000; Meyer et al., 1977).

Second, decoupling and hybridizing strategies are potentially costly for organizations since they require from organizational members to come up with alternative ways of doing things and to sustain these hybrid practices over the long run. Institutional logics provide organizational members with "ready-to-wear" practices that can be adopted by organizations with minimal cognitive and material efforts. In contrast, organizations that resort to decoupling have to mobilize energy and resources to develop the ceremonial required to fake compliance. Other hybridizing strategies that combine competing practices in alternative ways require from organizations to come up with a new organizing model for the practice, which, as a combination of two existing templates, may require specific adaptations. For example, SOCYCLE's strategy to combine both non-profit and for-profit status was indeed costly since it required the organization to satisfy both non-profit as well as for-profit administrative and regulatory requirements. TEMPORG and WORK\&CO's strategies to mobilize a combination of profit and for-profit shareholders required from their leadership to spend time socializing the various actors and appeasing the potential tensions emerging between shareholders with different goals and motivations. In contrast, the combination of intact practices borrowed from the two competing logics is an efficient strategy because it relies solely on the mobilization of well known available templates.

Finally, decoupling and hybridizing strategies at the practice level are potentially risky for organizations because they entail the potential dissatisfaction of institutional referents. In trying to satisfy all demands only partially, organizations challenge their institutional referents and run the risk of jeopardizing their support. By fully addressing some of the demands exerted by each institutional referent, organizational leaders may be in safer ground.

Importantly, the data suggests that the responses patterns crafted by these four organizations allowed them to avoid major legitimacy threats and to sustain their activities 
over the long run: the four organizations not only survived for more than 11 years after founding (and up to 22 years for SOCYCLE), but all of them achieved performance levels (in terms of turnover, number of social employees hired, as well as annual growth rates in the last three years) superior to the average in the field (see Table 1 for detailed numbers). Balancing competing demands at the organization level thus appears as a viable response to competing institutional demands.

Interestingly, the cross-case analysis reveals that although all organizations in the sample adopted the approach of reconciling logics at the organizational level instead of the practice level, the response patterns identified for each case suggest differences in the way through which organizations achieved this balance, in particular given their founding origins.

\section{Organizations' founding origins as a determinant of response patterns}

Organizational behavior is often guided by norms and values embedded in specific activities. Occupational groups and professions, in particular, have been identified as powerful carriers of institutional logics (Hirsch, 1986; Thornton et al., 2005). For example, Hwang and Powell (2009) show that management professionals hired by nonprofit organizations introduced rationalizing managerial practices in a sector traditionally exempt from rationalization concerns. Building upon this view, one would expect that professionals socialized into a given institutional logic would carry over this logic even in other fields. In the context of our study, one would expect organizations originating from the commercial sphere to adopt primarily commercial practices given the embeddedness of their professionals in the commercial logic, and organizations emanating from the social sector to adopt primarily social welfare practices, under the influence of social sector professionals.

Surprisingly, our data suggests a different dynamic. A striking pattern in our sample is that organizations that emanate from the commercial sector (i.e. organizations that were founded by or in close partnership with a business company) adopted predominantly social 
welfare practices, and more so than organizations emanating from the social sector (i.e. organizations that were founded by or in close partnership with a social sector organization). In contrast, organizations originating from the social sector adopted a balanced combination of intact social welfare and commercial practices, including more commercial practices than organizations originating from the commercial sector.

The TEMPORG/WORK\&CO pair illustrates this dynamic. TEMPORG was rooted in the social sector. It was launched in the early nineties as a subsidiary of France's most prominent social integration group founded by two social workers, pioneers of the social integration sector. WORK\&CO emanates from the commercial sector. It was created as a wholly owned subsidiary of MULTIWORK (a leading multinational group in the temporary work industry) by two training managers who viewed social integration temporary work as a strategic development for their company, as well as an expression of their own values.

Surprisingly, where one would have expected TEMPORG to adopt predominantly social welfare practices, it in fact adopted predominantly commercial practices (six out of ten). It chose a for-profit legal status and adopted a branching structure to operate sites, as well as a strong uniform brand. In addition, it allocated resources to monitor and control standard procedures, affiliated with temporary work professional organizations and decided not to mobilize volunteers. Only three out of the ten practices adopted by TEMPORG complied with the social welfare logic: the nonprofit appropriation, the mobilization of local advisory boards as well as the affiliation with social integration professional organizations. Similarly, given its roots, WORK\&CO could be expected to adopt primarily commercial practices. It did exactly the opposite. It adopted six social welfare practices out of ten. Whereas its mother organization was set up as a global web of tightly controlled branches with a very strong brand and standardized procedures, WORK\&CO chose to operate its sites as autonomous legal entities, with no common brand, no common procedures and no monitoring and control over the sites. Sites where piloted by volunteer managers from the 
mother organization, and required to affiliate with the social integration professional organization. Only two out of ten commercial practices were fully respected: the for-profit legal status, as well as the compulsory site affiliation with the temp work professional organization. Overall, TEMPORG, the organization with social origins, behaved more like a commercial organization than like a social organization, and, in any case, more commercially than WORK\&CO did. In contrast, WORK\&CO, the organization with commercial origins, behaved more like a social organization than like a business, and, in any case, more like a social organization than TEMPORG did.

The SOCYCLE/BUSITECH pair exhibits a similar pattern. BUSITECH, which was founded by young retirees of the multinational IT firm COMPUTER, under the impulse of its president for France, adopted only one commercial practice: it chose to operate its sites as for profit entities. On all other nine dimensions, BUSITECH chose to borrow practices from the social welfare logic. In contrast, SOCYCLE, which was founded with close ties to COMMUNITY, a very prominent international social organization, adopted five social welfare practices and four commercial practices. And whereas it combined both social welfare and commercial practices, it adopted more commercial practices than BUSITECH did.

Table 9 provides evidence for this pattern with a comparison of the four organizations.

Insert Table 9 about here

Our informants' accounts suggest potential explanations for these unexpected behaviors. One of our informants with WORK\&CO shared: "(When we started to work on the creation of our first social integration enterprise in 1991), everybody was after us, especially the social sector actors. Because we came to eat off their plate. Because we were big, people were afraid of us. Why would we do this job? Necessarily, to make money. And this would bother them. This was not our playground.” BUSITECH leaders shared similar perceptions: "People from the social world did not like us to enter their private preserve. They considered 
us as business executive with no experience in the social sector. And because there was COMPUTER (their mother organization) behind us, they said: "They want their toy. These days, it is good for companies to get involved in social activities, so they do it too. They come to eat our bread.”" This resistance was further demonstrated by the reaction of the local representatives of the State approached to obtain the social integration accreditation. A WORK\&CO informant recalls: “They clearly told us: don't even bother filing your application. It will never get accepted.” BUSITECH also received a first refusal from the accreditation commission for its site in Bordeaux and had to mobilize the regional prefect to get their application accepted the second time.

These findings suggest that in a field dominated by a social mission, organizations with a commercial imprint (BUSITECH and WORK\&CO) suffered from an a priori legitimacy deficit that seriously jeopardized their very existence and in turn influenced their response strategy. WORK\&CO leaders, for instance, initially considered adopting the commercial practice of creating wholly owned social integration subsidiaries. Negative reactions from the regional union of social integration enterprises led them to devise an alternative strategy: "We decided to use a chameleon tactic. They think we are the bad guys? Then we are going to prove them, in practice, that we are not. And we are going to learn that job that we don't know.” WORK\&CO leaders subsequently decided to systematically partner with well respected local social actors and to become minority shareholders in these autonomous organizations. By 1996, ten such organizations had been launched, borrowing heavily, in terms of organizing practices, from the social welfare logic template. BUSITECH also decided to ally with a prominent social partner in its Paris site. The president of BUSITECH's partner organization explained: “Their image as former COMPUTER executives did not really fit with a social project. The partnership that they built with us convinced the accreditation commission to grant BUSITECH with the right to operate as a social integration enterprise." Alliances were thus used by both BUSITECH and 
WORK\&CO to enhance their social legitimacy (Dacin, Oliver \& Roy, 2007). Yet, in addition to alliance strategies, BUSITECH and WORK\&CO overwhelmingly adopted social welfare practices when scaling their operations, despite these organizations' commercial origins.

Legitimacy concerns thus appear to play a very important role in influencing hybridization patterns. Organizations with a commercial imprint chose to compensate their initial legitimacy deficit by displaying a very high level of compliance with social welfare demands. In doing so, they attempted to demonstrate, in practice, the sincerity of their social intentions. These findings provide empirical support for strategic approaches to managing organizational legitimacy (Ashforth \& Gibbs, 1990; Suchman, 1995): organizations that perceive strong legitimacy threats as they enter a new field take a combination of substantive and symbolic actions to restore their legitimacy and to gain the required support to operate. Yet, our findings expands existing predictions by suggesting that organizations that engage in strategically managing their legitimacy in fields with enduring competing demands not only adopt the templates favored in the new field but largely give up on their original organizational templates.

Our data further suggests that organizations with a social imprint (SOCYCLE \& TEMPORG), benefited from an a priori legitimacy capital. No one a priori feared that an organization created by former members COMMUNITY, a highly legitimate social sector organization, would depart from its social integration mission. As a result, these organizations were able to liberate themselves - at least partially - from institutional influences. They were thus able to borrow more freely from alternative templates, and in particular from the commercial logic template. These findings echo Sherer and Lee’s (2002) study which showed that highly legitimate law firms where more free to depart from the dominant recruitment model in the field because their high level of legitimacy protected them from the fear of losing institutional support. What our study shows is that this pattern goes beyond the adoption of a single practice in a context of experimentation: legitimate actors in the field of 
social integration reconfigured a whole set of practices borrowed from social welfare and commercial influences. This was made possible by the relative cognitive autonomy conferred by these organizations' exposure to competing institutional templates.

It is important to stress that these departures from social welfare practices, in a field dominated by a social welfare mission, did not undermine SOCYCLE's and TEMPORG's legitimacy. After more than fifteen years of operations, both of them still clearly benefited from substantial political and public support in addition to support from commercial and industrial partners, as well as very high levels of recognition and reputation. Interestingly, both exhibited the highest performance level for social integration enterprises in their respective industries. TEMPORG was able to recruit 700 FTE social employees in 2007 where the average temp work company hires 35 FTE. SOCYCLE mobilized 800 social employees, where the average recycling enterprise mobilized 15 FTE. While we cannot draw direct implications from a comparison with the general population of organizations, this data suggests that the response combination crafted by SOCYCLE and TEMPORG allowed securing a broad range of social and political support, enabling them to scale up operations and maximize social impact by integrating more long-term unemployed people into the work force. Their initial social welfare legitimacy, combined with a minimal level of compliance with social welfare templates, was enough to please their social constituencies. As a result, they were able to gain local political support, mobilize public funds, secure the sourcing of social employees as well as guarantee their mentoring by partner social organizations. Their ability to display, in addition, compliance with the commercial logic, allowed them gain credibility with their commercial constituencies. They were able to interact on a more equal footing with industrial partners, clients and investors, and to negotiate, as a result, more favorable conditions to sustain their commercial activity. Their hybrid configuration, which differed on the structural practices related to legal status and ownership but was remarkably similar on the seven operational practices, allowed them to develop an organizational form 
that combines a high level of central control and coordination with a high level of local engagement. This organizational model enabled them to "get the best of both worlds".

\section{DISCUSSION}

We started this research endeavor by asking how organizations that are permanently embedded in competing institutional logics manage the resulting competing demands. A thorough examination of organizations in the field of social integration enterprises in France allowed us to discover that, under such conditions, the traditional prediction of practice-level decoupling (Meyer et al., 1977), while occasionally mobilized, was not predominant as a response strategy. Rather, organizations attempted to strike a balance at the organizational level by adopting a combination of intact practices from each logic. Our findings thus suggest that, by focusing on practice-level response strategies, institutional theorists may have overlooked important response strategies to competing institutional logics. In particular, our study offers contributions to institutional theory in three areas: by emphasizing the role of strategic isomorphism, identifying the importance of original legitimacy capital, and developing our understanding of hybrid organizations.

Strategic isomorphism. Our study sheds a new light on the debate about the role of agency in institutional theory. In particular, we provide evidence to the fact that, in the face of competing institutional demands, organizations do not blindly comply with institutional scripts (DiMaggio \& Powell, 1983) nor with the cognitive templates that they have been socialized into (Hwang et al., 2009). In the field of social integration, organizations with social origins were not trapped in mimicking social practices, just as organizations with commercial origins were not cognitively constrained to replicate commercial practices. In contrast, our data suggests that organizations are able to devise strategic responses to the competing demands they are exposed to (Oliver, 1991). In particular, we identify "strategic isomorphism” (Aurini, 2006) - the pattern of selectively complying with institutional 
templates - as a viable strategy for organizations that operate in fields exhibiting enduring competing demands. Interestingly, this process not only led the four organizations to vary in their compliance patterns to prevailing institutional practices, but it also led the organizations with similar founding origins to adopt similar patterns of response in terms of the number of pure practices that they combined from each logic.

In contrast to decoupling, which entails the ceremonial espousal of a practice with no actual implementation, strategic isomorphism refers to the purposeful adoption, by organizations, of selected practices among a pool of competing alternatives. Strategic isomorphism allows organizations to satisfy symbolic concerns, just as decoupling does. Accounts from our informants emphasize the symbolic power of some adopted practices - the most visible ones - which were adopted with the purpose of projecting appropriateness, as illustrated by this quote by one of SOCYCLE's site directors, who explains his choice to develop a new entity with a for-profit legal status: “A nonprofit can be really professional, but, in people's mind, a nonprofit is not-for-profit, it is not professional, it is not strong, financially. So we wanted to enter this competitive space with a business image." In environments where the scrutiny of institutional referents is hard to avoid, such as in environments characterized by high levels of fragmentation and moderate or high levels of centralization, strategic isomorphism appears as a safer and thus more viable strategy than decoupling because it does not put organizations at risk of being caught faking compliance. Similarly, strategic isomorphism also appears as superior to practice-level hybridizing strategies, such as balancing or compromising (Oliver, 1991) because it keeps organizations from having to engage in multiple negotiations with institutional referents or from having to craft new practices that are a compromise on practices promoted by each logic. As such, it is a less costly strategy, thus potentially more accessible to resource-constrained organizations.

Original Legitimacy Capital. Another important contribution of our work is the identification of organizational founding origins and their associated legitimacy endowment 
as a determinant of the pattern of strategic isomorphism. Previous research has identified status (Sherer et al., 2002) or position in the field (Greenwood \& Suddaby, 2006; Leblebici, Salancik, Copay \& King, 1991) as important organizational determinants of organizational responses to institutional influences. Our paper suggests that the founding origins of an organization also play an important role in determining its initial degree of social acceptance within a given field. This impacts, in turn, whether or not the organization is likely to deviate from the predominant institutional templates. Our data shows that in a field that remains dominated by its social mission, organizations that emanate from the social sector are freer to adopt templates drawn from other logics because they rely on a priori legitimacy capital. Because of this capital, institutional referents do not question the organization's good faith. Organizations can thus depart from the dominant practices to adopt competing ones. In contrast, organizations that emanate from the commercial sector are perceived as "original sinners” and thus suffer from an initial legitimacy deficit because their motives to enter a field with a social mission are questioned. To restore their legitimacy, they are constrained to demonstrate their fit with the predominant social logic. They overcompensate for this initial legitimacy deficit by adopting practices from the predominant logic - and more so than their social counterparts in order to demonstrate their appropriateness and secure social support.

Founding origins (by making organizations insiders or outsiders in a given field) thus influence greatly an organization's legitimacy capital and in turn its capacity to mobilize a combination of competing practices. This finding challenges the view of organizations as incarnations of institutional logics (Kraatz et al., 2008), which argues that cultural understandings imprinted in organizational forms at the time of founding constrain organizations throughout their lives (Haveman \& Rao, 1997; Rao et al., 2003). Our study shows that under conditions of enduring competing logics, founding imprinting may trigger change rather than inertia by allowing organizations to deviate from their original institutional logic. 
Hybrid organizations. A key contribution of our paper is offering a better understanding of hybrid organizations. Hybrids, defined as organizations that combine in unprecedented ways different institutional logics (Scott et al., 1991) are becoming more prevalent as the phenomenon of competing logics is itself becoming more widespread (Pache et al., 2010; Scott et al., 1991; Seo et al., 2002). While recent studies have paid increasing attention to the emergence of this specific type of organizations (Battilana et al., 2010; D'Aunno et al., 1991; Haveman et al., 1997; Haveman \& Rao, 2006; Rao et al., 2003; Reay et al., 2009), we still know little about the specificities of managing hybrid organizations, other than their hiring and socialization practices (Battilana et al., 2010) or their collaboration strategies (Reay et al., 2009). Our research focuses specifically on the balancing of practices that allows hybrid organizations to scale up.

Our study suggests that hybrid organizations do not hybridize their practices - or only marginally so - but rather adopt a combination of intact practices borrowed from the logics they are embedded in. This finding builds upon the conception of logics as "cultural tookits" (Swidler, 1986; Tracey et al., 2010) which people can use in various configurations to solve different kinds of problems. A great strength of hybrids is thus that they have access to a much broader repertoire of practices from which they can borrow and combine in unique ways. This places them at an advantage if they are able to craft a configuration of practices that fits with the demands from their environment and helps them leverage a wider range of support. Yet this strategy also exposes organizations to greater risks of internal conflict among members who might champion competing logics (Pache et al., 2010), as well as conflict with external stakeholders who hold competing expectations. Extant research indeed highlights that hybridization is potentially challenging for organizations and that hybrid organizations are unlikely to survive (Aurini, 2006; Battilana et al., 2010; Meyer et al., 1977). Our findings provide explanations for how and in what conditions organizations can overcome these challenges. 
First, while the taken-for-grantedness of institutional prescriptions may be weakened by the existence of alternative models, these competing models may still strongly influence internal groups within the organizations, thereby channeling inside the organization the fieldlevel conflict of logics (Battilana et al., 2010; D'Aunno et al., 1991; Pache et al., 2010; Zilber, 2002). For example, in their study of a matched pair of commercial microfinance organizations, Battilana and Dorado (2010) found that the organization that had attempted to hybridize their workforce by recruiting staff adhering to the two competing logics available in the field (the banking logic and the development logic) was unable to prevent conflicts and misunderstanding among the two sub-groups (bank workers and social workers) that they were trying to integrate. Zilber (2002) highlights a similar pattern of conflict among organizational members adhering to competing logics in a rape crisis center. Our findings suggest that hybrid organizations can escape these harmful internal conflicts and ensure their sustainability if they are not confronted with (or are able to avoid) institutional conflict on goals and if they are able to manage institutional conflict on what practices to adopt by strategically combining intact practices from both institutional worlds.

Second, even if organizations were to avoid these internal conflicts by recruiting members free from any institutional attachments (Battilana et al., 2010), they nevertheless face the challenge of securing support and resources from institutional referents embedded in these antagonistic logics. To signal their appropriateness and gain such support, they need to comply, at least partially, with the competing practices prescribed by these institutional referents. Such a process, leading to the internalization of competing practices (D'Aunno et al., 1991; Meyer et al., 1977), is again a potential source of internal tensions. We find that the selective adoption of intact practices can enable organizations to please institutional referents and thus secure widespread support. Our findings also suggest that organizations may be able to strategically distinguish between the important signaling practices that will cue institutional referents to the goals and motivations of the organization (such as profit versus non-profit 
status) from the practices that can be more freely adopted and combined as they are less "loaded" with meaning.

Third, empirical research has shown that an organization's ability to depart from institutional scripts and to borrow from alternative templates is influenced by its position in a field (Leblebici et al., 1991), by its status (Sherer et al., 2002) as well as by its exposure to alternative logics (Greenwood et al., 2006). This research suggest that all organizations are not equally able to become hybrids and that an organization's initial embeddedness in a given logic might play a critical role in constraining or enabling the hybridization process. We contribute to this literature by suggesting that organizations that have a priori legitimacy capital, due to their original embeddedness in the predominant logic, may be able to craft a stable and valuable combination of practices that borrows freely from the competing logics. In contrast, organizations that are born outside the predominant logic face a legitimacy deficit that forces them to adopt almost fully the organizational script of the predominant logic.

Overall, our findings suggest that there is value in exploring the phenomenon of organizational responses to competing institutional demands at the organization level. By focusing on the symbolic versus substantive adoption of a specific practice in a field, previous decoupling studies might have overlooked a much more complex dynamic involving the strategic combination of substantive practices. In our research, by raising the level of analysis from the practice to the organizational level, we move from a view of organizational leaders as actors taking symbolic actions, pretending to adopt practices while decoupling their organizational core, to organizational leaders as bricoleurs (Baker \& Nelson, 2005; Mair \& Marti, 2009) who perform institutional work (Lawrence \& Suddaby, 2006), combining the templates and scripts afforded by a richer institutional environment, while learning to navigate the minefields created by enduring institutional conflicts. In doing so, we contribute to the development of the micro-foundations of institutional theory, called upon by Powell 
and Colyvas (2008) and shed light into "why institutional practices and structures take the form that they do (p.295)”.

We believe that our findings have broader applicability beyond instances of competition between commercial and social welfare logics. Our sample was selected on the basis of the existence of conflicting demands, rather than on the content of these demands. Further, our findings are not specific to the social welfare or commercial sector logics and may apply more broadly to any field subject to institutional clashes, such as the clash between medical professionalism and business logics (Reay et al., 2009) or care versus science logic (Dunn et al., 2010). Thus, the strategic combination of pure practices, enacted by organizations that possess or are able to acquire initial legitimacy capital, may provide a blueprint for the development of sustainable hybrid organizations in different organizational field that face competing and enduring institutional demands.

Yet, much remains to be explored in this stream of research. Although we started to explore when and how hybrid organizations are able to combine competing institutional logics in unprecedented ways, future research needs to clarify in which situations hybrids may become a superior organizational form. As suggested by Kraatz and Block (2008) in their review of organizational implications of institutional pluralism, organizations that are able to embody multiple logics in a sustainable way are likely to be ultimately more legitimate and thus to garner more efficiently the social and material support that they require to thrive. Such performance study would require an in-depth study of the survival and performance of organizations adopting a hybrid model compared to peer institutions remaining faithful to a single logic. It would also require exploring the role played by organizational leaders in this process, to understand what explains their ability to combine different institutional logics in a strategic way. 


\section{CONCLUSION}

Overall, hybrid organizations defined as those that are able to combine competing institutional logics in unprecedented ways (Scott et al., 1991) are becoming increasingly prevalent in society as organizations increasingly face competing institutional logics. The rise of the field of social enterprise, of which social integration organizations are one of the examples, attests to this trend. Yet, the specific management practices that allow organizations to combine competing institutional logics to form hybrids have been understudied. In addition, their ability to survive and grow as a hybrid has been questioned by current literature (Aurini, 2006; Battilana et al., 2010). Our study sheds a new light into this emergent phenomenon and advanced our understanding of hybrid organizations.

Conflicts in institutional logics can be experienced at the level of goals or at the level of means/practices required to achieve these goals (Pache et al., 2010). Our research shows that as long as the conflict on goals is resolved at the field level by a central actor, hybrid organizations, especially the ones that benefit from a priori legitimacy by virtue of their founding origins, are able to combine pure practices from the different institutional logics, thus developing a distinctive organizing template that allows them to effectively scale their operations. This suggests that hybrids may be a viable organizational form that can exhibit distinct advantages in complex and permanently conflicting institutional environments. 


\section{REFERENCES}

Ashforth, B. E., \& Gibbs, B. W. 1990. The double edge of organizational legitimation. Organization Science, 1(2): 177-194.

Aurini, J. 2006. Crafting Legitimation Projects: An Institutional Analysis of Private Education Businesses. Sociological Forum, 21(1): 83-111.

Baker, T., \& Nelson, R. E. 2005. Creating Something from Nothing: Resource Construction through Entrepreneurial Bricolage. Administrative Science Quarterly, 50(3): 329-366.

Basu, O. N., Dirsmith, M. W., \& Gupta, P. P. 1999. The coupling of the symbolic and the technical in an institutionalized context: The negotiated order of the GAO's audit reporting process. American Sociological Review, 64(4): 506-526.

Battilana, J., \& Dorado, S. 2010. Building sustainable hybrid organizations: The case of commercial microfinance organizations. Academy of Management Journal, (in press).

Binder, A. 2007. For love and money: Organizations' creative responses to multiple environmental logics. Theory and society, 36: 547-571.

Boxenbaum, E., \& Jonsson, S. 2008. Isomorphism, diffusion and decoupling. In R. Greenwood, C. Oliver, R. Suddaby, \& K. Sahlin-Andresson (Eds.), The Sage Handbook of Organziational Institutionalism: 840. London: Sage.

Brunsson, N. 2002. The Organziation of Hypocrisy. Oslo: Abstract Liber.

Chandler, A. D. 1977. The Visible Hand. Boston: Belknap.

Chen, K. K., \& O'Mahony, S. 2006. The selective synthesis of competing logics. Paper presented at the Academy of Management Proceedings.

Clemens, E. S., \& Cook, J. M. 1999. Politics and institutionalism: Explaining durability and change. Annual review of sociology, 25: 441-466. 
D'Aunno, T. A., Sutton, R. I., \& Price, R. H. 1991. Isomorphism and external support in conflicting institutional environments: A study of drug abuse treatment units. Academy of Management Journal, 34(3): 636-661.

Dacin, M. T., Oliver, C., \& Roy, J. P. 2007. The legitimacy of strategic alliances: An institutional perspective. Strategic Management Journal, 28: 169-187.

Di Maggio, P., \& Anheier, H. K. 1990. The sociology of nonprofit organizations and sectors. Annual review of sociology(16): 137-159.

DiMaggio, P., \& Powell, W. W. 1983. The iron cage revisited: Institutional isomorphism and collective rationality in organizational fields. American Sociological Review, 48: 147160.

Djelic, M. L., \& Quack, S. 2004. Globalization and institutions: Redefining the rule of the economic game. Northampton, M.A.: Edward Elgar.

Dorado, S. 2005. Institutional entrepreneurship, partaking and convening. Organization Studies, 26(3): 385-414.

Dunn, M. B., \& Jones, C. 2010. Institutional Logics and Institutional Pluralism: The Contestation of Care and Science Logics in Medical Education, 1967--2005. Administrative Science Quarterly, 55(1): 114-149.

Edelman, L. 1992. Legal ambiguity and symbolic structures: Organizational mediation of Civil Rights Law. American Journal of Sociology, 97: 1531-1576.

Edelman, L. B., Abraham, S. E., \& Erlanger, H. S. 1992. Professional construction of law: The inflated threat of wrongful discharge". Law \& Society Review, 26: 47-94.

Eisenhardt, K. M. 1989. Building Theories from Case Study Research. Academy of Management Review, 14(4): 532.

Elsbach, K. D., \& Sutton, R. I. 1992. Acquiring organizational legitimacy through illegitimate actions: A marriage of institutional and impression management theories. Academy of Management Journal, 35(4): 699-738. 
Fiss, P. C., \& Zajac, E. J. 2004. The diffusion of idea over contested terrain: The (non)adoption of a shareholder value orientation among German firms. Administrative Science Quarterly, 49: 501-534.

Fiss, P. C., \& Zajac, E. J. 2006. The symbolic management of strategic change: Sensegiving via framing and decoupling. Academy of Management Journal, 49(6): 1173-1193.

Fligstein, N. 1996. Markets as politics: A political-cultural approach to market institutions. American Sociological Review, 61(August): 656-673.

Friedland, R., \& Alford, R. R. 1991. Bringing society back in: Symbols, practices, and institutional contradictions. In W. W. Powell, \& P. DiMaggio (Eds.), The New Institutionalism in Organizational Analysis: 232-263. Chicago: The University of Chicago Press.

Frumkin, P. 2002. On being nonprofit. Cambridge, MA: Harvard University Press.

George, E., Chattopadhyay, P., Sitkin, S. B., \& Barden, J. 2006. Cognitive underpinnings of institutional persistence and change: A framing perspective. Academy of Management Review, 31(2): 347-365.

Glynn, M. A. 2000. When cymbals become symbols: Conflict over organizational identity within a symphony orchestra. Organization Science, 11(3): 285-298.

Glynn, M. A., \& Lounsbury, M. 2005. From the critic's corner: Logic blending, discursive change and authenticity in a cultural production system. Journal of Management Studies, 42(5): 1031-1055.

Greenwood, R., Diaz, A. M., Li, S. X., \& Lorente, J. C. 2010. The Multiplicity of Institutional Logics and the Heterogeneity of Organizational Responses. Organization Science, 21(2): 521-539.

Greenwood, R., \& Hinings, C. R. 1996. Understanding Radical Organizational Change: Bringing Together the Old and the New Institutionalism. Academy of Management Review, 21(4): 1022. 
Greenwood, R., \& Suddaby, R. 2006. Institutional entrepreneurship in mature fields: The big five accounting firms. Academy of Management Journal, 49(1): 27-48.

Haveman, H. A. 2000. The future of organizational sociology: Forging ties among paradigms. Contemporary sociology, 29: 476-486.

Haveman, H. A., \& Rao, H. 1997. Structuring a theory of moral sentiments: Industrial and organizational co-evolution in the early thrift industry. American Journal of Sociology, 102(6): 1606-1651.

Haveman, H. A., \& Rao, H. 2006. Hybrid forms and the evolution of thrift. American Behavioral Scientist, 49(7): 974-986.

Heimer, C. A. 1999. Competing institutions: Law, medicine and family in neonatal intensive care. Law \& Society Review, 33(1): 17-66.

Hirsch, P. M. 1986. From Ambushes to Golden Parachutes: Corporate Takeovers as an Instance of Cultural Framing and Institutional Integration. American Journal of Sociology, 77: 800-837.

Hoffman, A. J. 1999. Institutional evolution and change: Environmentalism and the U.S. chemical industry. Academy of Management Journal, 42(4): 351-371.

Hugues, J. M., \& Gasse, M. 2004. Face à la crise, de vraies entreprises, CNEI Mag, Vol. 26: 20-23.

Hwang, H., \& Powell, W. W. 2009. The Rationalization of Charity: The Influences of Professionalism in the Nonprofit Sector. Administrative Science Quarterly, 54(2): 268-298.

Kostova, T., \& Roth, K. 2002. Adoption of an organizational practice by subsidiaries of multinational corporations: Institutional and relational effects. Academy of Management Journal, 45(1): 215-233. 
Kraatz, M. S., \& Block, E. S. 2008. Organizational Implications of Institutional Pluralism. In R. Greenwood, C. Oliver, R. Suddaby, \& K. Sahlin-Andresson (Eds.), The Sage Handbook of Organizational Institutionalism: 840. London: Sage.

Lawrence, T. B., \& Suddaby, R. 2006. Institutions and institutional work. In S. Clegg, C. Hardy, T. B. Lawrence, \& W. R. Nord (Eds.), The Sage Handbook of Organization Studies: 215-254. Thousand Oaks, CA: SAGE.

Leblebici, H., Salancik, G. R., Copay, A., \& King, T. 1991. Institutional change and the transformation of interorganizational fields: An organizational history of the U.S. radio broadcasting industry. Administrative Science Quarterly, 36(3): 333-363.

Lounsbury, M. 2005. Competing logics and the spread of recycling advocacy groups. In G. F. Davis, D. McAdam, W. R. Scott, \& M. N. Zald (Eds.), Social Movements and Organizationa Theory. NYC: Cambridge University Press.

Lounsbury, M. 2007. A tale of two cities: competing logics and practice variation in the professionalizing of mutual funds. Academy of Management Journal, 50(2): 289307.

Mair, J., \& Marti, I. 2009. Entrepreneurship in and around institutional voids: A case study from Bangladesh. Journal of Business Venturing, 24(5): 419-435.

Meyer, J., Scott, W. R., \& Strang, D. 1987. Centralization, fragmentation and school district complexity. Administrative Science Quarterly, 32: 186-201.

Meyer, J. W., \& Rowan, B. 1977. Institutionalized organizations: Formal structure as myth and ceremony. American Journal of Sociology, 83(2): 340-363.

Nelson, R. R., \& Winter, S. G. 1982. An Evolutionary Theory of Economic Change. Cambridge, MA: Belknap.

Nigam, A., \& Ocasio, W. 2009. Event Attention, Environmental Sensemaking, and Change in Institutional Logics: An Inductive Analysis of the Effects of Public Attention to Clinton's Health Care Reform Initiative. Organization Science: orsc.1090.0490. 
Oliver, C. 1991. Strategic responses to institutional processes. Academy of Management Review, 16(1): 145-179.

Pache, A. C., \& Santos, F. 2010. When worlds collide: The internal dynamics of organizational responses to conflicting institutional demands. Academy of Management Review, 35(3): 455-476.

Pauly-Aboubadra, S. 2004. Le temps des pionniers, CNEI Mag, Vol. 26: 6-9.

Pfeffer, J., \& Salancik, G. R. 1978. The External Control of Organizations: A Resource Dependence Perspective. New York, NY: Harper and Row.

Powell, W. W., \& Colyvas, J. A. 2008. Microfoundations of Institutional Theory. In R. Greenwood, C. Oliver, R. Suddaby, \& K. Sahlin-Andresson (Eds.), The Sage Handbook of Organizational Institutionalism: 840. London: Sage.

Powell, W. W., \& Friedkin, R. 1986. Politics and programs: Organizational factors in public television decision making. In P. DiMaggio (Ed.), Nonprofit enterprise in the arts: 245-269. New York: Oxford University Press.

Purdy, J. M., \& Gray, B. 2009. Conflicting logics, mechanisms of diffusion and multilevel dynamics in emerging institutional fields. Academy of Management Journal, 2(52).

Rao, H., Monin, P., \& Durand, R. 2003. Institutional change in Toque Ville: Nouvelle Cuisine as in identity movement in French gastronomy. American Journal of Sociology, 108(4): 795-843.

Reay, T., \& Hinings, C. R. 2009. Managing the rivalry of competing institutional logics. Organization Studies, 30(06): 629-652.

Ring, P. S., Bigley, G., D'Aunno, T., \& Khanna, T. 2005. Perspectives on how governments matter. Academy of Management Review, 30(2): 308-320.

Scott, W. R. 1987. The Adolescence of Institutional Theory. Administrative Science Quarterly, 32(4): 493-511. 
Scott, W. R. 1994. Conceptualizing organizational fields: Linking organizations and societal systems. In H. Derlien, U. Gerhardt, \& H. Scharpf (Eds.), Systemrationalitat un Partialinteresse: 203-221. Baden-Baden: Nomos Verlagsgesellschaft.

Scott, W. R. 2001. Institutions and organizations (2nd ed.). Thousand Oaks, Calif.: Sage Publications.

Scott, W. R. 2003. Organizations: Rational, Natural and Open Systems (4th ed.). Upper Saddle River, NJ: Prentice Hall.

Scott, W. R., \& Meyer, J. W. 1991. The organization of societal sectors: Propositions and early evidence. In W. W. Powell, \& P. DiMaggio (Eds.), The new institutionalism in organizational analysis: 108-142. Chicago, IL: The University of Chicago Press.

Seo, M., \& Creed, W. E. D. 2002. Institutional contradictions, praxis and institutional change: A dialectical perspective. Academy of Management Review, 27(2): 222-247.

Sherer, P. D., \& Lee, K. 2002. Institutional Change in Large Law Firms: A Resource Dependency and Institutional Perspective. Academy of Management Journal, 45(1): 102.

Stevens, J. M., Steensma, H. K., Harrison, D. A., \& Cochran, P. L. 2005. Symbolic or substantive document? The influence of ethics codes on financial executives' decisions. Strategic Management Journal, 26(2): 181-195.

Suchman, M. C. 1995. Managing legitimacy: Strategic and institutional approaches. Academy of Management Review, 20(3): 571-610.

Swidler, A. 1986. Culture in Action: Symbols and Strategies. American Sociological Review, 51(2): 273-286.

Thornton, P. H. 2002. The rise of the corporation in a craft industry: conflict and conformity in institutional logics. Academy of Management Journal, 45(1): 81-101. 
Thornton, P. H., Jones, C., \& Kury, K. 2005. Institutional logics and institutional change in organizations: transformation in accounting, architecture and publishing. Research in the Sociology of Organizations, 23: 125-170.

Thornton, P. H., \& Ocasio, W. 1999. Institutional Logics and the Historical Contingency of Power in Organizations: Executive Succession in the Higher Education Publishing Industry, 1958-1990., American Journal of Sociology, Vol. 105: 801-844: University of Chicago Press.

Thornton, P. H., \& Ocasio, W. 2008. Institutional Logics. In R. Greenwood, C. Oliver, R. Suddaby, \& K. Sahlin-Andresson (Eds.), The Sage Handbook of Organizational Institutionalism: 840. London: Sage.

Tracey, P., Phillips, N., \& Jarvis, O. 2010. Bridging Institutional Entrepreneurship and the Creation of New Organizational Forms: A Multilevel Model. Organization Science: orsc.1090.0522.

Westphal, J. D., Gulati, R., \& Shortell, S. M. 1997. Customization or Conformity? An Institutional and Network Perspective on the Content and Consequences of TQM Adoption. Administrative Science Quarterly, 42(2): 366.

Westphal, J. D., \& Zajac, E. J. 1994. Substance and symbolism in CEOs' long-term incentive plans, Administrative Science Quarterly, Vol. 39: 367-390: Administrative Science Quarterly.

Westphal, J. D., \& Zajac, E. J. 1998. The Symbolic Management of Stockholders: Corporate Governance Reforms and Shareholder Reactions., Administrative Science Quarterly, Vol. 43: 127-153: Administrative Science Quarterly.

Westphal, J. D., \& Zajac, E. J. 2001. Decoupling policy from practice: The case of stock repurchase programs. Administrative Science Quarterly, 46: 202-228.

Yin, R. K. 2003. Case study research: Design and methods. Thousand Oaks, MA: Sage. 
Zajac, E. J., \& Westphal, J. D. 1995. Accounting for the explanations of CEO compensations: Substance and symbolism. Administrative Science Quarterly, 40: 283-308.

Zilber, T. B. 2002. Institutionalization as an interplay between actions, meaning and actors: the case of a rape crisis center in Israel. Academy of Management Journal, 45(1): 234-254.

Zilber, T. B. 2006. The work of symbolic in institutional processes: translations of rational myths in Israeli high tech. Academy of Management Journal, 49(2): 281-303. 


\section{APPENDIX 1}

\section{The field of social integration enterprises in France}

\section{Key Figures}

In 2007, $1098^{2}$ social integration enterprises existed in France, 44 percent of them operating under a non-profit status, and 56 percent of them operating under a for-profit status $^{3}$. The average social integration enterprise mobilized 1 million Euros in revenues, 80 percent of which from sales. Other revenues included the above mentioned state contribution, as well as other public or private grants. The average enterprise hired 24 FTE employees, 15 of which were "social employees". The largest social integration enterprise in France hired 2300 FTE employees across the country and was largely diversified (operating in the temp work, gardening, catering, moving and construction industries).

\section{History}

The first social integration enterprises were created at the end of the 70's by social workers who, in the context of the emerging economic crisis, found it increasingly frustrating to see youths at risk and people without professional qualification face difficulties to join "regular" companies. Recognizing the limits of the social approaches sponsored by their social organizations (targeting primarily health, housing or poverty issues) to address jobrelated issues, they decided to create commercial subsidiaries - initially called "intermediary companies" - that were specifically designed to help unemployed people learn the skills of work. They offered social employees paid short term contracts, focusing on activities that were simple enough to be accessible to people without qualification and organized a close and indulgent supervision to accompany social employees in the learning process.

Rapidly identified by policy makers concerned by the increasing unemployment rates, and benefiting from the lobbying efforts deployed by the pioneers of the field, these experimentations were progressively legitimized through various laws (in 1979, 1985, 1991, 1998 and 2006) which granted them with the right and duty to operate as real economic entities. These laws adapted the French labor law to allow social integration companies to resort systematically and repeatedly to fixed-term contracts for their social employees ${ }^{4}$. In turn, they required social integration companies to pay social employees at minimum wage and to comply with legal and fiscal requirements. National policy makers rapidly institutionalized public financial support, in compensation for the costs incurred by the extra supervision requirements and the below-average productivity of social employees. This

\footnotetext{
${ }^{2}$ Source : Ministry of Work Data 2007

${ }^{3}$ Source: National Federation of Social Integration Enterprises Data 2007

${ }^{4}$ Fixed-term contracts are, under the French labor law, officially reserved to specific circumstances (temporary or seasonal increase in activity, replacement of a sick employee, etc.).
} 
national recognition, together with the support provided by local governments, helped the field structure and develop.

Over the years, social integration enterprises grew more and more separate from the social institutions which had founded them. While this initial affiliation had helped social integration entrepreneurs reach out to social policy makers, it also generated tensions with traditional social actors who viewed them as "joining forces with the bosses" or as "exploiters" (Pauly-Aboubadra, 2004). The scattered initiatives that had flourished across France thus felt a growing need to join efforts and collaborate. The first regional union of social integration enterprises was created in 1983, soon followed by other regional unions, which led to the creation of the national federation of social integration enterprises (CNEI) in 1988 and the formalization of the first charter of social integration enterprises. In turn, the growing visibility of the field led to the emergence of tensions with the commercial sector, which started to perceive these new enterprises as unfair competitors, due to the public subsidies that they received.

Since the 90's, in the face of the aggravation of the economic crisis, social integration enterprises consolidated their position as both social and economic actors. With unemployment rate reaching heights (up to 14 percent between 1994 and 1998), and with an increase in the time required for jobless people to find a job (in 1995, 40 percent of unemployed people had been looking for work for more than one year), social integration enterprises became an important building block of local and national employment policies. During that period, they developed partnerships with local governments, and often obtained access to local public funds in addition to the regulated state subsidy. They developed relationships with the public national employment agency, in charge of identifying potential social employees, as well as with local social and public actors in charge of social and professional integration issues locally. Yet under pressure to sustain their economic activities, social integration entrepreneurs progressively adopted "business entrepreneurs" practices (Hugues \& Gasse, 2004). Entrepreneurs with social backgrounds invested in management trainings and entrepreneurs with new profiles, business school graduates as well as more experienced former business executives, started to join the field (Hugues et al., 2004). This trend consolidated in the years 2000, as more and more organizations in the field voiced their identity as "real companies", started to join employers unions, and partnered with capitalist businesses to develop business opportunities. In the middle of the years 2000, social integration enterprises were thus integrated in both the social and the economic sphere. 
TABLE 1

Description of cases

\begin{tabular}{|c|c|c|c|c|}
\hline Cases & SOCYCLE & TEMPORG & BUSITECH & WORK\&CO \\
\hline Number of interviews & 17 & 12 & 12 & 7 \\
\hline Industry & Recycling & Temp Work & Recycling & Temp Work \\
\hline Activity & Recycle used white goods & $\begin{array}{l}\text { Offer temp work services } \\
\text { to private companies }\end{array}$ & Recycle used computers & $\begin{array}{c}\text { Offer temp work services } \\
\text { to private companies }\end{array}$ \\
\hline Number of sites & 48 & 23 & 5 & 5 \\
\hline Founding year & 1985 & 1991 & 1995 & 1994 \\
\hline Scaling year & 1988 & 1993 & 1995 & 1994 \\
\hline Founding origins & Social Sector & Social Sector & Business Sector & Business Sector \\
\hline Total Staff (FTE) & 1070 & 840 & 40 & 200 \\
\hline $\begin{array}{l}\text { Number of “social } \\
\text { employees” (included) }\end{array}$ & 800 & 700 & 30 & 170 \\
\hline Total resources & $28 \mathrm{M} €$ & $21 \mathrm{M} €$ & $1,6 \mathrm{M} €$ & $5 \mathrm{M} €$ \\
\hline Sales / Total resources & $70 \%$ & $85 \%$ & $80 \%$ & $85 \%$ \\
\hline
\end{tabular}


TABLE 2

Competing belief systems of the social welfare and commercial logics

\begin{tabular}{|c|c|c|c|c|}
\hline DIMENSION & $\begin{array}{l}\text { SOCIAL } \\
\text { WELFARE } \\
\text { LOGIC }\end{array}$ & $\begin{array}{l}\text { SUPPORTING STATEMENTS FOR } \\
\text { SOCIAL WELFARE LOGIC }\end{array}$ & $\begin{array}{l}\text { COMMERCIAL } \\
\text { LOGIC }\end{array}$ & $\begin{array}{l}\text { SUPPORTING STATEMENTS FOR } \\
\text { COMMERCIAL LOGIC }\end{array}$ \\
\hline $\begin{array}{l}\text { Organization's } \\
\text { focus of attention }\end{array}$ & $\begin{array}{l}\text { Social employees } \\
\text { (i.e. long term } \\
\text { unemployed people) } \\
\text { are the main focus } \\
\text { of attention of the } \\
\text { organization }\end{array}$ & $\begin{array}{l}\text { "The risk is that one day, we decide to select people } \\
\text { when they join the organization. "Let's refuse this one } \\
\text { because we won't be able to do anything with him". } \\
\text { My main mission is to give everybody a chance, } \\
\text { precisely those who are rejected by other employers." } \\
\text { (SOCYCLE site manager) }\end{array}$ & $\begin{array}{l}\text { Clients (i.e. } \\
\text { purchasers of goods } \\
\text { and services) are the } \\
\text { main focus of } \\
\text { attention of the } \\
\text { organization }\end{array}$ & $\begin{array}{l}\text { "We are no charities. We have to know who we deal } \\
\text { with: with clients who are demanding, who have their } \\
\text { own constraints, who have their own criteria. We have } \\
\text { to listen to their concerns, to their needs and find the } \\
\text { best possible solutions for them. Then we can take the } \\
\text { social dimension into account." } \\
\text { (WORK \& Co site manager) }\end{array}$ \\
\hline Production & $\begin{array}{l}\text { Products and } \\
\text { services should be } \\
\text { adapted to local } \\
\text { social needs }\end{array}$ & $\begin{array}{c}\text { "It is very important to know your community well, if } \\
\text { you want to address their needs. What legitimacy do } \\
\text { we have to impose our model in neighboring } \\
\text { communities? None. We are no imperialists. But we'll } \\
\text { help them if they ask us to." } \\
\text { (Field informant) }\end{array}$ & $\begin{array}{l}\text { Products and } \\
\text { services should be } \\
\text { consistent and } \\
\text { uniform across } \\
\text { market }\end{array}$ & $\begin{array}{l}\text { "It is clear, our main partner has no patience with our } \\
\text { internal debates, and with the fact that our people in } \\
\text { city } X \text { want to do things differently than our people in } \\
\text { city } Y . \text { They want a single contact person and a single } \\
\text { way to do things. Else they'll go see our competitors." } \\
\text { (SOCYCLE federation manager) }\end{array}$ \\
\hline $\begin{array}{c}\text { Control } \\
\text { mechanism }\end{array}$ & $\begin{array}{l}\text { Democratic control } \\
\text { is the appropriate } \\
\text { way to monitor } \\
\text { strategy and } \\
\text { operations }\end{array}$ & $\begin{array}{l}\text { "It was important to give people (i.e. local entities) a } \\
\text { say in the decisions, to give them ownership of the } \\
\text { project, to collectively discuss orientations and } \\
\text { possible evolutions. It seemed to me more democratic } \\
\text { than the functioning we had where a tight group was } \\
\text { taking all the decisions and the others would } \\
\text { execute." } \\
\text { (SOCYCLE board member) }\end{array}$ & $\begin{array}{l}\text { Hierarchical control } \\
\text { is the appropriate } \\
\text { way to monitor } \\
\text { strategy and } \\
\text { operations }\end{array}$ & $\begin{array}{l}\text { "Off course, our site entrepreneurs have to be } \\
\text { responsible and autonomous, and we put the systems in } \\
\text { place to make sure they are, but at the same time, we } \\
\text { want to control, evaluate and monitor them." } \\
\text { (TEMPORG executive director) }\end{array}$ \\
\hline Goal & $\begin{array}{l}\text { Overall goal is to } \\
\text { address social needs } \\
\text { (i.e. contribute to } \\
\text { the work } \\
\text { integration of long } \\
\text { term unemployed } \\
\text { people) }\end{array}$ & $\begin{array}{c}\text { "The goal is to make sure that these people find a } \\
\text { permanent job. Temp work is only a means to achieve } \\
\text { our social aims. We are not in for profits or } \\
\text { dividends." } \\
\text { (TEMPORG site manager) }\end{array}$ & $\begin{array}{l}\text { Overall goal is to } \\
\text { generate and } \\
\text { redistribute profits }\end{array}$ & $\begin{array}{c}\text { "When we discussed about having COMPUTER, our } \\
\text { mother organization, invest capital in BUSITECH, we } \\
\text { thought: "Definitely not, the Americans will never } \\
\text { understand what a social integration enterprise is } \\
\text { about and they will ask for dividends.”” } \\
\text { (BUSITECH executive director) }\end{array}$ \\
\hline
\end{tabular}


TABLE 3

Competing scale up practices

\begin{tabular}{|c|c|c|c|c|c|}
\hline & PRACTICES & CONTENT & SOCIAL WELFARE LOGIC & COMMERCIAL LOGIC & MEASURE \\
\hline \multirow{3}{*}{ 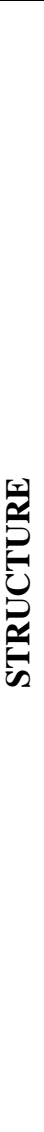 } & $\begin{array}{c}\text { Organizational } \\
\text { form }\end{array}$ & $\begin{array}{l}\text { What is the } \\
\text { legitimate } \\
\text { organizational form } \\
\text { of sites? }\end{array}$ & $\begin{array}{c}\text { Autonomous entities } \\
\text { Sites should be structured as autonomous entities } \\
\text { that allow for tailoring products and services to } \\
\text { local social needs and for the mobilization of local } \\
\text { support. } \\
\text { "We could have chosen to develop as a group with } \\
\text { subsidiaries, but we wouldn't have had access to } \\
\text { volunteers in local boards who have close ties with } \\
\text { local funders and were able to mobilize local } \\
\text { support.” (SOCYCLE national board member) }\end{array}$ & $\begin{array}{l}\text { Branches or wholly owned entities } \\
\text { Sites should be structured as entities that allow for } \\
\text { coordination and homogenization of actions to } \\
\text { ensure consistency in goods and services. } \\
\text { "What was atypical for MULTIWORK was to } \\
\text { create autonomous legal entities, because at } \\
\text { MULTIWORK, they create clones or secondary } \\
\text { establishments.” (WORK\&CO national } \\
\text { coordinator) }\end{array}$ & $\begin{array}{l}\text { Legal structure of } \\
\text { sites }\end{array}$ \\
\hline & Legal status & $\begin{array}{l}\text { What is the } \\
\text { legitimate legal } \\
\text { status of operating } \\
\text { sites? }\end{array}$ & $\begin{array}{l}\text { Non profit form } \\
\text { Sites should be formed as nonprofit entities } \\
\text { because that legal status is the best safeguard } \\
\text { against mission drift. } \\
\text { "The non profit status obliges us to keep our focus } \\
\text { on social integration. If we would change statuses, } \\
\text { even with our current board, some would say "let's } \\
\text { go make profits". (SOCYCLE site board member) }\end{array}$ & $\begin{array}{l}\text { For profit form } \\
\text { Sites should be formed as for profit entities } \\
\text { because they are professional commercial entities. } \\
\text { "We chose a for profit status because we operate } \\
\text { in a competitive space and we needed an image } \\
\text { different from a non-profit. A nonprofit can be really } \\
\text { professional but in people's minds, a nonprofit is not for } \\
\text { profit, it is not professional, it is not strong financially. } \\
\text { So we wanted to enter this competitive space with a } \\
\text { business image." (BUSITECH founder) }\end{array}$ & $\begin{array}{l}\text { Incorporation status } \\
\text { of sites }\end{array}$ \\
\hline & Ownership & $\begin{array}{l}\text { Who are the } \\
\text { legitimate owners of } \\
\text { the sites? }\end{array}$ & $\begin{array}{c}\text { Mission guardians } \\
\text { The legitimate owners of sites are those who } \\
\text { define, promote and protect the social mission of } \\
\text { the organization. } \\
\text { "This non profit, owing } 20 \% \text { of the shares, is } \\
\text { composed of volunteers, who are the owners - put } \\
\text { it in brackets- and the guardians of the company's } \\
\text { social mission. They are leaders who historically } \\
\text { participated in the group's definition of its social } \\
\text { mission." (TEMPORG executive director) }\end{array}$ & $\begin{array}{l}\text { Capital holders } \\
\text { The legitimate owners of sites are those who have } \\
\text { invested capital in the sites. } \\
\text { "I don't want to create a company that generates } \\
\text { surplus and makes shareholders happy.” } \\
\text { (BUSITECH founder) }\end{array}$ & $\begin{array}{l}\text { Dominant ownership } \\
\text { of sites }\end{array}$ \\
\hline
\end{tabular}




\section{Reinvestment in social mission}

The legitimate use of profits is their reinvestment

in the mission of the organization.

Profit What is the destination legitimate use of profit?

"What we want is to generate surplus to create jobs or to train those who work with us. (...) If we generate surplus, which we do, we create new jobs,

we create a new company or hire - as we did recently - a social worker or training

expert."(SOCYCLE site manager)

\section{Involvement of local actors in site} governance

Local actors, who are legitimate experts of local needs, should be involved in the leadership of local What is the

Local legitimate level of involvement of loca actors in site governance?

"There is one thing that I really shouldn't do: recreate the multinational company that I worked for 30 years. So the idea is that if there are local entrepreneurs willing to launch a BUSITECH site, we are willing to help them, to share our knowhow and to have them join our network. We are ready to help, but the locals have to take the lead." (BUSITECH founder)

\section{Localized}

The brand should be defined at the local level, as a

way for local actors to express their autonomy and

identity.
"What our partners buy is our deep knowledge of

$\begin{gathered}\text { Brand (name, is the } \\ \text { identity) }\end{gathered}$
$\begin{gathered}\text { legitimate scope for } \\ \text { brand identity? }\end{gathered}$
the community, our local networks. This is what matters most to them. The brand, the looks and all that does not matter do them that much." (Field expert)

\section{Locally adapted procedures}

Procedures should adapted at the local level to adapt to the specific needs and resources of the

What is the

localization of

operating

operating
procedures?

$$
\text { local environment. }
$$

" "Locally, there is a nonprofit which is in charge, responsible and which is close to the field and thus knows what can be done and what cannot be done. It is not an entity in Paris that should tell this site:

"this is what you should do."” (SOCYCLE national board member)
Appropriation by private interests

The legitimate use of profits is the distribution of

dividends in proportion to the capital invested.

"MULTI WORK (WORK\&CO mother

organization) is now managed from Zurich and

Chicago and these guys know nothing about social

Surplus distribution

practices

integration in France. So at some point, they will

ask for a return on investment." (WORK\&CO national coordinator)

\section{No involvement of local actors needed in}

\section{site governance}

Experts, mobilized at the national level, are

legitimate to address organizational and strategic

$$
\text { challenges. }
$$

"It is a great comfort to know that everything is controlled in headquarters. We have experts on

various issues, such as legal affairs, accounting, management and social work. If we are in trouble,

we know exactly whom to contact." (TEMPORG

$$
\text { site manager) }
$$

Systematic

involvement of local actors in site governance

\section{Unified}

The brand should be unified across all sites to project consistency in identity and quality.

project consistency in identity and quality.
"When I talk about our network made of different Branding uniformity:

brands to large companies, they look at me, puzzled, asking: "what is that thing?" (WORK\&CO deputy coordinator)

Common visual identity?

\section{Standard operating procedures}

Procedures should be standardized to because this is a potential source of cost reduction and

$$
\text { efficiency. }
$$

"One of the issues with our site managers is that they are not systematic and regular with sales initiatives. So we hired a national sales director who will define a real planned national sales strategy, and who should do what." (TEMPORG
Existence and enforcement of SOP in HR, Accounting,
IT, Training, Sales, Pricing? executive director) 


\section{Local monitoring of sites}

No central resources are needed to monitor sites

because practices designed at the local level should also be controlled at the local level.

What is the
Monitoring legitimate level site monitoring?

we share ideas, where we don't force things. Mark and myself, we are social, so we decided we would not impose things. There is a whole ideology behind that posture." (WORK\&CO deputy coordinator)

\section{Social integration federation}

The social integration federation is the place where the interests of social integration professionals are best represented and promoted.

What is the

Professional legitimate affiliatio affiliation with professiona
organizations?

"It is important that there is a structure that helps us as social integration enterprises, that represents us, that does lobbying when necessary. So I chose to remain affiliated with them." (BUSITECH

$$
\text { founder) }
$$

\section{Mobilization of volunteers}

(including in operational positions)

What is the

Mobilization legitimate use of of volunteers $\quad \begin{gathered}\text { volunteers as a } \\ \text { human resource? }\end{gathered}$

resources because they embody the values of solidarity and disinterested commitment to a cause.
"Why is a nonprofit better? Because (...) it allows for the mobilization of volunteers. What I like about it is that there is no self interest. So people's sole motivation is what we do." (Field informant)

\section{Central monitoring of sites}

Centrally designed standard procedures should be

monitored centrally, thus requiring the mobilization

of resources at the central level.

"If you want quality, there is no way out of

monitoring sites and helping them to learn from

each other." (TEMPORG executive director)

Royalties paid by

sites to fund central

monitoring

organization

\section{Industry federation}

The recycling or temp work industry federations are the places where the interests of recycling and temp work are best represented and promoted

"The affiliation with PRISME (temp work

professional association) is indispensable in terms

of image. It means that we are serious."

$$
\text { (WORK\&CO site manager) }
$$

Systematic site membership with professional organization

\section{No mobilization of volunteers}

Volunteers are unknown resources in the

commercial sector, where paid professionals are the only legitimate human resources.

"One cannot create a real company with members who are totally volunteers. That is good for charitable organizations, for the Red Cross or other places like that." (BUSITECH founder)
Existence of volunteers in operational position other than board 
TABLE 4

SOCYCLE's Response strategy to competing social welfare and commercial logic in 2007

\begin{tabular}{|c|c|c|c|c|c|}
\hline & PRACTICE & MEASURE & $\begin{array}{l}\text { PURE SOCIAL WELFARE } \\
\text { PRACTICE }\end{array}$ & $\begin{array}{c}\text { DECOUPLED AND HYBRID } \\
\text { PRACTICE } \\
\end{array}$ & $\begin{array}{c}\text { PURE COMMERCIAL } \\
\text { PRACTICE } \\
\end{array}$ \\
\hline \multirow{3}{*}{ 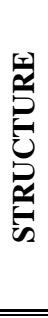 } & Organizational form & Legal form of sites & $\begin{array}{c}\text { Sites are autonomous legal } \\
\text { entities }\end{array}$ & & \\
\hline & Legal status & Incorporation status of sites & & $\begin{array}{l}\text { A combination of nonprofit } \\
\text { and for profit sites }\end{array}$ & \\
\hline & Ownership & Dominant ownership of sites & $\begin{array}{c}\text { All sites (including for profit } \\
\text { ones) are owned by a local } \\
\text { non profit }\end{array}$ & & \\
\hline \multirow{7}{*}{ 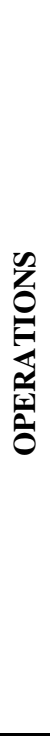 } & Profit destination & Surplus distribution practices & No profit appropriation & & \\
\hline & Local embeddedness & $\begin{array}{l}\text { Systematic involvement of local } \\
\text { actors in site governance }\end{array}$ & $\begin{array}{c}\text { Governance by local boards of } \\
\text { directors composed of local } \\
\text { actors }\end{array}$ & & \\
\hline & Brand & $\begin{array}{l}\text { Branding uniformity: } \\
\text { Common name? } \\
\text { Common visual identity? }\end{array}$ & & & $\begin{array}{c}\text { Common name }+ \\
\text { common brand identity }+ \\
\text { common communication tools }\end{array}$ \\
\hline & Procedures localization & $\begin{array}{c}\text { Existence and enforcement of } \mathrm{SO}_{\underline{\underline{P}}} \\
\text { in HR, Accounting, IT, Training, } \\
\text { Sales, Pricing? }\end{array}$ & & $\begin{array}{l}\text { Decoupled standardization } \\
\text { (formal procedures written } \\
\text { yet not always applied) }\end{array}$ & \\
\hline & Monitoring & $\begin{array}{l}\text { Royalties paid by sites to fund } \\
\text { central monitoring organization }\end{array}$ & & & $\begin{array}{c}\text { Sites pay } 3 \% \text { of their turnover } \\
\text { to HQ }\end{array}$ \\
\hline & Professional affiliation & $\begin{array}{l}\text { Systematic site membership with } \\
\text { professional organization }\end{array}$ & Yes (all sites) & & Yes (all sites) \\
\hline & $\begin{array}{l}\text { Mobilization of } \\
\text { volunteers }\end{array}$ & $\begin{array}{l}\text { Existence of volunteers in } \\
\text { operational positions other than } \\
\text { board }\end{array}$ & & & $\begin{array}{c}\text { No volunteers in operational } \\
\text { functions other than board } \\
\text { members }\end{array}$ \\
\hline \multicolumn{3}{|c|}{ TOTAL NR OF PRACTICES ADOPTED } & 5 & 2 & 4 \\
\hline
\end{tabular}


TABLE 5

TEMPORG's Response strategy to competing social welfare and commercial logic in 2007

\begin{tabular}{|c|c|c|c|c|c|}
\hline & CONSTRUCT & MEASURE & $\begin{array}{c}\text { PURE } \\
\text { SOCIAL WELFARE } \\
\text { PRACTICE } \\
\end{array}$ & $\begin{array}{l}\text { DECOUPLED AND } \\
\text { HYBRID PRACTICES }\end{array}$ & $\begin{array}{c}\text { PURE } \\
\text { COMMERCIAL } \\
\text { PRACTICE } \\
\end{array}$ \\
\hline \multirow{3}{*}{ 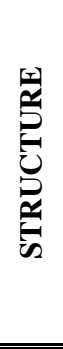 } & Organizational form & Legal form of sites & & & $\begin{array}{l}\text { Sites are branches of a } \\
\text { national organization }\end{array}$ \\
\hline & Legal status & Incorporation status of sites & & & $\begin{array}{l}\text { All sites operated under the } \\
\text { for profit status }\end{array}$ \\
\hline & Ownership & Dominant ownership of sites & & $\begin{array}{c}\text { Combination of private and } \\
\text { nonprofit shareholders (with } \\
\text { slight majority to nonprofit } \\
\text { organization) }\end{array}$ & \\
\hline \multirow{7}{*}{ 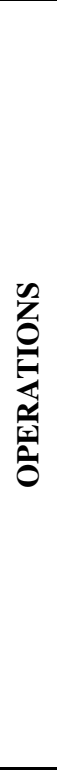 } & Profit destination & Surplus distribution practices & $\begin{array}{c}\text { No profit appropriation } \\
\text { (moral agreement among } \\
\text { shareholders) }\end{array}$ & & \\
\hline & Local embeddedness & $\begin{array}{l}\text { Systematic involvement of local } \\
\text { actors in site governance }\end{array}$ & $\begin{array}{c}\text { Mobilization of local } \\
\text { advisory boards with local } \\
\text { actors required for all sites }\end{array}$ & & \\
\hline & Brand & $\begin{array}{l}\text { Branding uniformity: } \\
\text { Common name? } \\
\text { Common visual identity? }\end{array}$ & & & $\begin{array}{c}\text { Common name + common } \\
\text { brand identity }\end{array}$ \\
\hline & Procedures localization & $\begin{array}{l}\text { Existence and enforcement of } \\
\text { SOP, in HR, Accounting, IT, } \\
\text { Training, Sales, Pricing? }\end{array}$ & & $\begin{array}{l}\text { Some common procedures } \\
\text { and autonomy on others }\end{array}$ & \\
\hline & Monitoring & $\begin{array}{l}\text { Royalties paid by sites to fund } \\
\text { central monitoring organization }\end{array}$ & & & $\begin{array}{l}\text { Sites pay } 4,5 \% \text { of their } \\
\text { turnover to } \mathrm{HQ}\end{array}$ \\
\hline & Professional affiliation & $\begin{array}{l}\text { Systematic site membership with } \\
\text { professional organization }\end{array}$ & $\begin{array}{c}\text { Yes } \\
\text { (All sites) }\end{array}$ & & $\begin{array}{c}\text { Yes } \\
\text { (All sites) }\end{array}$ \\
\hline & Mobilization of volunteers & $\begin{array}{c}\text { Existence of volunteers in } \\
\text { operational positions other than } \\
\text { board }\end{array}$ & & & No \\
\hline \multicolumn{3}{|c|}{ TOTAL NR OF PRACTICES ADOPTED } & 3 & 2 & 6 \\
\hline
\end{tabular}


TABLE 6

BUSITECH's Response strategy to competing social welfare and commercial logic in 2007

\begin{tabular}{|c|c|c|c|c|c|}
\hline & CONSTRUCT & MEASURE & $\begin{array}{c}\text { PURE } \\
\text { SOCIAL WELFARE } \\
\text { PRACTICE } \\
\end{array}$ & $\begin{array}{l}\text { DECOUPLED AND } \\
\text { HYBRID PRACTICES }\end{array}$ & $\begin{array}{c}\text { PURE } \\
\text { COMMERCIAL } \\
\text { PRACTICE } \\
\end{array}$ \\
\hline \multirow{3}{*}{ 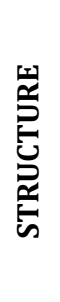 } & Organizational form & Legal form of sites & $\begin{array}{c}\text { Sites are autonomous legal } \\
\text { entities }\end{array}$ & & \\
\hline & Legal status & Incorporation status of sites & & & All sites are for profit \\
\hline & Ownership & Dominant ownership of sites & $\begin{array}{c}\text { Each for profit site is owned } \\
\text { by a non profit }\end{array}$ & & \\
\hline \multirow{7}{*}{ 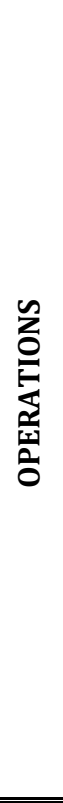 } & Profit destination & Surplus distribution practices & & $\begin{array}{l}\text { Occasional profit } \\
\text { redistribution }\end{array}$ & \\
\hline & Local embeddedness & $\begin{array}{l}\text { Systematic involvement of local } \\
\text { actors in site governance }\end{array}$ & $\begin{array}{c}\text { Governance by local boards } \\
\text { of directors composed of } \\
\text { local actors }\end{array}$ & & \\
\hline & Brand & $\begin{array}{l}\text { Branding uniformity: } \\
\text { Common name? } \\
\text { Common visual identity? }\end{array}$ & & $\begin{array}{l}\text { Decoupled branding: } \\
\text { common name, but no } \\
\text { common identity and } \\
\text { communication tools }\end{array}$ & \\
\hline & Procedures localization & $\begin{array}{l}\text { Existence and enforcement of } \\
\text { SOP, in HR, Accounting, IT, } \\
\text { Training, Sales, Pricing? }\end{array}$ & No common procedures & & \\
\hline & Monitoring & $\begin{array}{l}\text { Royalties paid by sites to fund } \\
\text { central monitoring organization }\end{array}$ & $\begin{array}{c}\text { No resources allocated to } \\
\text { monitoring }\end{array}$ & & \\
\hline & Professional affiliation & $\begin{array}{l}\text { Systematic site membership with } \\
\text { professional organization }\end{array}$ & & $\begin{array}{l}\text { Some sites decide to affiliate } \\
\text { with industry }+ \text { social } \\
\text { professional organizations }\end{array}$ & \\
\hline & Mobilization of volunteers & $\begin{array}{c}\text { Existence of volunteers in } \\
\text { operational positions other than } \\
\text { board }\end{array}$ & $\begin{array}{l}\text { Most sites operations run by } \\
\text { volunteers ( } 20 \text { volunteers } \\
\text { mobilized in operations) }\end{array}$ & & \\
\hline \multicolumn{3}{|c|}{ TOTAL NR OF PRACTICES ADOPTED } & 6 & 3 & 1 \\
\hline
\end{tabular}


TABLE 7

WORK\&CO’s Response strategy to competing social welfare and commercial logic in 2007

\begin{tabular}{|c|c|c|c|c|c|}
\hline & CONSTRUCT & MEASURE & $\begin{array}{c}\text { PURE } \\
\text { SOCIAL WELFARE } \\
\text { PRACTICE } \\
\end{array}$ & $\begin{array}{l}\text { DECOUPLED AND HYBRID } \\
\text { PRACTICES }\end{array}$ & $\begin{array}{c}\text { PURE } \\
\text { COMMERCIAL } \\
\text { PRACTICE } \\
\end{array}$ \\
\hline \multirow{3}{*}{ 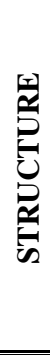 } & Organizational form & Legal form of sites & $\begin{array}{c}\text { Sites are autonomous legal } \\
\text { entities }\end{array}$ & & \\
\hline & Legal status & Incorporation status of sites & & & $\begin{array}{l}\text { All sites operated under the } \\
\text { for profit status }\end{array}$ \\
\hline & Ownership & Dominant ownership of sites & & $\begin{array}{c}\text { Combination of capitalist and } \\
\text { non profit shareholders (with } \\
\text { slight majority to capitalist } \\
\text { shareholders) } \\
\end{array}$ & \\
\hline \multirow{7}{*}{ 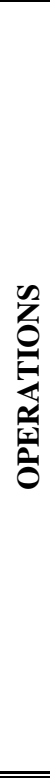 } & Profit destination & Surplus distribution practices & & $\begin{array}{l}\text { Decoupled redistribution: } \\
\text { announces no redistribution } \\
\text { yet occasionally redistributes }\end{array}$ & \\
\hline & Local embeddedness & $\begin{array}{l}\text { Systematic involvement of } \\
\text { local actors in site governance }\end{array}$ & & $\begin{array}{l}\text { Local ownership by local } \\
\text { shareholders only }\end{array}$ & \\
\hline & Brand & $\begin{array}{l}\text { Branding uniformity: } \\
\text { Common name? } \\
\text { Common visual identity? }\end{array}$ & $\begin{array}{c}\text { No common brand: no } \\
\text { common name + no } \\
\text { identity }\end{array}$ & & \\
\hline & Procedures localization & $\begin{array}{c}\text { Existence and enforcement of } \\
\text { SOP } \text { in HR, Accounting, IT, } \\
\text { Training, Sales, Pricing? }\end{array}$ & $\begin{array}{c}\text { No standard operating } \\
\text { procedures }\end{array}$ & & \\
\hline & Monitoring & $\begin{array}{l}\text { Royalties paid by sites to fund } \\
\text { central monitoring } \\
\text { organization }\end{array}$ & $\begin{array}{c}\text { No resources allocated to } \\
\text { monitoring }\end{array}$ & & \\
\hline & Professional affiliation & $\begin{array}{l}\text { Systematic site membership } \\
\text { with professional organization }\end{array}$ & $\begin{array}{c}\text { Yes } \\
\text { (All sites) }\end{array}$ & & $\begin{array}{c}\text { Yes } \\
\text { (All sites) }\end{array}$ \\
\hline & Mobilization of volunteers & $\begin{array}{c}\text { Existence of volunteers in } \\
\text { operational positions other } \\
\text { than board }\end{array}$ & $\begin{array}{c}\text { Each site managed by a } \\
\text { volunteer manager } \\
\text { (5 volunteers })\end{array}$ & & \\
\hline \multicolumn{3}{|c|}{ TOTAL NR OF PRACTICES ADOPTED } & 6 & 3 & 2 \\
\hline
\end{tabular}

Deleted: :ף 
TABLE 8

Synthesis of Response patterns

\begin{tabular}{|c|c|c|c|c|c|c|c|c|c|c|c|c|}
\hline \multirow[b]{3}{*}{ PRACTICES } & \multicolumn{6}{|c|}{ ORGANIZATIONS WITH SOCIAL ORIGINS } & \multicolumn{6}{|c|}{ ORGANIZATIONS WITH BUSINESS ORIGINS } \\
\hline & \multicolumn{3}{|c|}{ SOCYCLE } & \multicolumn{3}{|c|}{ TEMPORG } & \multicolumn{3}{|c|}{ BUSITECH } & \multicolumn{3}{|c|}{ WORK\&CO } \\
\hline & Social & $\begin{array}{l}\text { Decoupled / } \\
\text { Hybrid }\end{array}$ & Commercial & Social & $\begin{array}{c}\text { Decoupled / } \\
\text { Hybrid }\end{array}$ & Commercial & Social & $\begin{array}{c}\text { Decoupled / } \\
\text { Hybrid }\end{array}$ & Commercial & Social & $\begin{array}{c}\text { Decoupled / } \\
\text { Hybrid }\end{array}$ & Commercial \\
\hline $\begin{array}{l}\text { Organizational } \\
\text { form }\end{array}$ & $\checkmark$ & & & & & $\checkmark$ & $\checkmark$ & & & $\checkmark$ & & \\
\hline Legal status & & $\checkmark$ & & & & $\checkmark$ & & & $\checkmark$ & & & $\checkmark$ \\
\hline Ownership & $\checkmark$ & & & & $\checkmark$ & & $\checkmark$ & & & & $\checkmark$ & \\
\hline Profit destination & $\checkmark$ & & & $\checkmark$ & & & & $\checkmark$ & & & $\checkmark$ & \\
\hline $\begin{array}{c}\text { Local } \\
\text { embeddedness }\end{array}$ & $\checkmark$ & & & $\checkmark$ & & & $\checkmark$ & & & & $\checkmark$ & \\
\hline $\begin{array}{l}\text { Procedures } \\
\text { localization }\end{array}$ & & $\checkmark$ & & & $\checkmark$ & & $\checkmark$ & & & $\checkmark$ & & \\
\hline Monitoring & & & $\checkmark$ & & & $\checkmark$ & $\checkmark$ & & & $\checkmark$ & & \\
\hline $\begin{array}{c}\text { Professional } \\
\text { affiliation }\end{array}$ & $\checkmark$ & & $\checkmark$ & $\checkmark$ & & $\checkmark$ & & $\checkmark$ & & $\checkmark$ & & $\checkmark$ \\
\hline $\begin{array}{l}\text { Mobilization of } \\
\text { volunteers }\end{array}$ & & & $\checkmark$ & & & $\checkmark$ & $\checkmark$ & & & $\checkmark$ & & \\
\hline $\begin{array}{c}\text { TOTAL \# OF } \\
\text { PRACTICES } \\
\text { ADOPTED }\end{array}$ & 5 & 2 & 4 & 3 & 2 & 6 & 6 & 3 & 1 & 6 & 3 & 2 \\
\hline
\end{tabular}


TABLE 9

Founding origins as a determinant of response strategies

\begin{tabular}{|c|c|c|c|}
\hline & \multicolumn{3}{|c|}{ TOTAL NUMBER OF PRACTICES ADOPTED } \\
\hline FOUNDING ORIGINS & $\begin{array}{c}\text { INTACT } \\
\text { SOCIAL WELFARE } \\
\text { PRACTICES }\end{array}$ & $\begin{array}{l}\text { DECOUPLED AND HYBRID } \\
\text { PRACTICES }\end{array}$ & $\begin{array}{c}\text { INTACT } \\
\text { COMMERCIAL } \\
\text { PRACTICES }\end{array}$ \\
\hline Social Sector & 5 & 2 & 4 \\
\hline Social Sector & 3 & 2 & 6 \\
\hline $\begin{array}{l}\text { TOTAL PRACTICES ADOPTED BY ORGANIZATIONS } \\
\text { ORIGINATING FROM THE SOCIAL SECTOR }\end{array}$ & 8 & 4 & 10 \\
\hline Commercial Sector & 6 & 3 & 1 \\
\hline Commercial Sector & 6 & 3 & 2 \\
\hline $\begin{array}{l}\text { TOTAL PRACTICES ADOPTED BY ORGANIZATIONS } \\
\text { ORIGINATING FROM THE COMMERCIAL SECTOR }\end{array}$ & 12 & 6 & 3 \\
\hline
\end{tabular}


ESSEC Business School Avenue Bernard Hirsch BP 50105

95021 Cergy-Pontoise Cedex France

Tél. + $33(0) 134433000$

Fax $+33(0) 134433001$

www.essec.fr

ESSEC Executive Education

CNIT BP 230

92053 Paris-La Défense

France

Tél. +33(0)146924900

Fax +33(0)1 46924990

http:l/formation.essec.fr

ESSEC Business School

Singapore Campus

100 Victoria Street

National Library Building \# 13-02

Singapore 188064

essecasia@essec.fr

Tél. +65 68849780

Fax +6568849781

www.essec.edu

\section{Informations}

Hanane Rahmoune +33 (0)134433358

rahmoune@essec.edu

www.essec.fr

research.center@essec.fr

ISSN 1291-9616 